東京在住在日韓国婦人の食物摂取と その周辺条件に関する研究

$$
\begin{aligned}
& \text { 季 誠國 }{ }^{*} \text { 豊川 裕之** 丸井 英二*** } \\
& \text { 矢ヶ崎信子 }{ }^{* * * *} \text { 金子 俊** 角田 俊一*** }
\end{aligned}
$$

\title{
Food Consumption Pattern and Social Factors on Korean Women Living in Tokyo
}

\section{Sung Kook LEE*, Hiroyuki TOYOKAWA**, Eiji MARUI***, Nobuko YAGASAKI****, Shun KANEKO** and Shun-ichi KAKUTA***}

Nutrition survey was held on 88 Korean women living at Adachi-ku, Tokyo, May 11-12, 1981, in order to make clear their food consumption pattern in comparison with Japanese women who were surveyed in terms of the same method by the authors. In addition, generation gap were also estimated among the Korean women.

1) Results in amounts of food consumed

The amount of food cosumed a day per capita was weighed and scaled so carefully that well-trained interviewers of nutritionists visited with them every days and supported them to weight and write on the recording paper. When amount of food consumed in each food-articles were compared between Korean and Japanese women, there were as reasonable differences as nation-wide differences between them in several food-articles, i.e., milk, noodle and vegetables which are consumed larger amount in Japanese than in Korean, and kimchies, rice, meat and processed food which were consumed larger amount in Korean than in Japanese.

There were very interesting results that the generation gaps between the first and the second generation of Koreans in Tokyo simulated the gaps between Korean food in their home country and Japanese food in National Nutrition Survey. In other say, Koreans in Tokyo are adapting to Japanese food in generation scale but not in simple chronological scale.

* 慶北大学校医科大学予防医学教室（当時：東京大学医学部疫学教室）

** 東邦大学医学部公衆衛生学教室（同 上）

*** 東京大学医学部度学教室

**** 女子栄養大学臨床栄養学研究室 (同 上)

* Department of Preventive Medicine \& Public Health, School of Medicine, Kyungpook National University, Korea.

** Dept. of Pub, Helth., School of Medicine, Toho University

*** Dept. of Epidemiology, School of Health Sciences, University of Tokyo

**** Dept. of Clinical Nutrition. Fac. of Medicine, Kagawa Nutrition College. 
2) Results in Food Consumption Structure

The correlation coefficients between all of food groups were shown in matrix which were named "Food Consumption Structure" by Toyokawa, H., a member of the authors. The food consumption structure was so characteristic in both of Korean two generations and the suburban Japanese female that there were much clear differences among them. These differences showed also an aspect of sociocultural association between Korea and Japan.

Principal factor analysis was able to show the results above into two dimensional diagram which consisted of both of the first factor eating pulses, milk and oil $\&$ fat and the second factor eating rice.

It should be concluded that the Korean women living in Tokyo have a dual structure consist of Korean culture and Japanese culture, and the dual structure in each individuals will probably continue throughout their lifespan.

\section{1 は じめに}

在日韓国人の生活実態は, その人数扣よび歴史 的関係が無視できないものであるにも拘らず，こ れまで調査研究報告は多くはない。とくに戦後に かぎるならばすくない，金（1971）は在日朝鮮人 の人口学的研究を通して在日朝鮮人の人口学的特 徵が母国よりも日本の文化的・社会的環境に類似 していることを述べ，さらに金（1977）は1965〜 1974年の在日韓国人の人口学的推移の特徵を過去 の非定着的・母国回帰型から定着的ないし現実適 応型へ転換しつつあると述べていることは注目さ れる. 本研究では人口学的な巨視的研究とは異な り, 特定な地域小集団の在日韓国人の生活実態を 微視的な実態調查を通して明らかにしたいと考兄 る。しかし生活実態は多面的生活行動に係るもの であって，その全貌を把握することは困難である ので, 食物摂取状況とその周辺状況に限って保健 学的立場から, 現状を明らかにすることは意義あ るものと考えられる。すなわち，食物摄取状況は 栄養問題とくに食生活の根幹であり，かつ種々の 健康事象に密接な関連があることは既に認められ ている.しかし，食物摄取状況を把握するに当たっ ては食物摄取状況に食物消費構造と総称される構 造的な実態があるので，その実態を無視して特定 の食品を個別に取り上げて検討するだけでは食物
摂取状況の実態を包括的に把握したことにはなら ないことが既に指摘されている(豊川1975，1976， 1978).そこで本研究では食物消費パターンによる 食物摂取状況分析の方法を導入して在日韓国人の 食物摂取状況を構造的に把握すると共に，食物摂 取状況とその周辺状況との係りを明らかにする. それによって金（1971）と金（1977）が在日韓国 人（または在日朝鮮人）の人口学的特色として報 告したことを食物摂取状況とその周辺状況の面か ら再検討するものである。

\section{II 調査対象および調査期間}

1. 調査対象と選出法

本調査研究の対象は東京都内で在日韓国人が最 も集中している足立区を選定した。行政資料によ れば足立区の外国人数は 6,932 人であり，その中 で，対象地区には3,446人 (49.7\%)の外国人が住 んでいる(東京都足立区1975)。この外国人のほと んど大部分が在日韓国人（朝鮮籍および韓国籍の 人)であることになる.な拉，対象の抽出に当たっ ては在日本大韓民国居留民団東京足立支部から名 簿をもらい, 1981年 1 月下旬から 4 力月間各家庭 を訪問して本調査の意義，内容についてょく説明 し, 協力を依頼して承諾した100世帯を対象に選 び, 主として各世帯の婦人に面接聞き取りとした。 Fig. 1 は調査地区の位置を示したものである. 


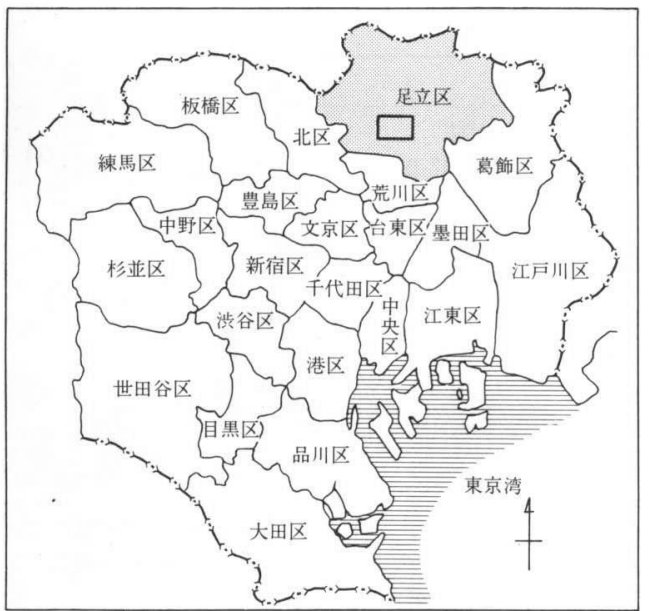

Fig. 1 Study area

\section{1）一般生活環境}

調查対象 100 世帯中, 実際の計算に用いた対象者 は 91 世帯であり, 主婦が日本婦人の 10 人と資料不 足 2 人を除いた 88 人である。とりあげた各要因の カテゴリー分布の結果を示すと Table 1-1, 1-2の と拉りである。

\section{2）主婦および配偶者の年齢}

配偶者の場合, 一世の平均年齢は54.6土8.1, 二 世は39.0土8.4である. 主婦の場合は一世の平均年

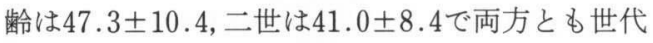
間に有意差が見られる。

3) 出身地

配偶者と主婦とも出身地別の人数は済州道, 慶 尚道, 全羅道の順である。これらの地域は日本と 近い所である。特に在日韓国人の出身地に関する 分析を見ると，済州道出身は，7割が阪神圏にい るといわれる。本調査地域の済州道出身者も大 阪・神戸から転住した人が多い.

\section{4) 在日年数}

一世婦人の在日年数は最短： 1 年, 最長 : 40 年 であり, 平均在日年数は $26.4 \pm 16.8$ で, 戦前（36 年前）から日本に居住している主婦が一番多い. 次いで10年未満の居住年数の主婦である。それは 最近本国の韓国から結婚によって日本に移住して きた主婦である。

\section{5) 教育程度}

配偶者の場合，一世は小学校卒以下が55.6\%， 二世は高校卒以上が $86.5 \%$ あ゙あ。主婦の場合， 一世は小学校卒以下が59.0\%，二世は $19.1 \%$ で両 方とも世代間有意差 $(\mathrm{p}<0.01)$ が見られる。一世 の教育程度が低いことは戦前日本に移住した韓国 人の大部分が農村出身で就学の少なかった事実を 反映している.

6) 職業

配偶者の職業はサンダル加工とミシン加工など 技能工，生産工程従事者が一世では $61.0 \%$ で圧倒 的に多く，二世では $37.9 \%$ 二ある。特に注目すべ

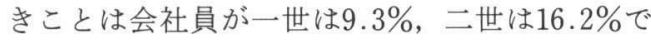
あって，共に低率であることである，次に主婦が 配偶者と一緒に働く割合は一世では60\%, 二世で は72.9\%である。

7）子供数扣よび家族数

子供数は現在一緒に住んでない子供も全部含め て計算した。平均子供数は一世で $3.2 \pm 1.8$ 人で 3 人以上が $62.5 \%$ ，その ちち 5 人以上が $22.5 \%$ で最 大であり，二世では平均子供数は $3.1 \pm 1.5$ 人で, 3 人以上が $66.6 \%$ であるが子供数の最頻值は 3 人 (29.2\%) である.

家族数は現在一緒に住んでいる家族だけをみる と一世は 5 人 $(30.8 \%)$ 二世世 4 人 $(29.2 \%)$ が 最も多い:そして一世带当たり平均家族数は一世 では $4.1 \pm 1.2$ 人，二世では $4.5 \pm 1.6$ 人であり，い ずれも有意差がない。一世の家族数が二世より少 ないことは子供が大きくなって, 独立し両親から 離れて暮らすためと考学られる。また，平均睡眠 時間は一世, 二世ともに約7.5時間である. 労働時

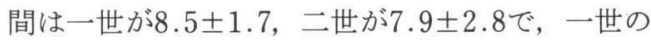
方が少し長く労働している。しかし，この地域は 大部分の世帯の職業が家内工業なので家事時間と 労働時間がはっきり区別でさない事情がある。対 象者の就労年数は一世は 10 年末満, 二世は $10 \sim 20$ 年末満が一番多い. 一方, 現在の生活上の悩みに ついては一世が経済問題（34.2\%）を挙げている が，二世では別に悩みはないとするものが約半数 であり子供の問題を挙げるものが $28.3 \%$ ある. 
Table 1-1 世代別生活環境

\begin{tabular}{|c|c|c|c|c|}
\hline 要 因 & カテゴリー & 一 世 & 二 世 & $x^{2 \text { 值 }}$ \\
\hline 年 齢 & $\sim 39$ & $2(3.7)$ & $23(62.2)$ & 42.53 \\
\hline \multirow{4}{*}{ 1）配偶者 } & $40 \sim 49$ & $12(22.3)$ & $10(27.0)$ & \\
\hline & $50 \sim 59$ & $20(37.0)$ & $3(8.1)$ & $\mathrm{p}<0.01$ \\
\hline & $60 \sim$ & $20(37.0)$ & $1(2.4)$ & \\
\hline & & $(\bar{X}=54.6 \pm 8.1)$ & $(\bar{X}=39.0 \pm 8.4)$ & \\
\hline \multirow[t]{4}{*}{ 2) 主 婦 } & -39 & $9(22.5)$ & $25(52.1)$ & 11.19 \\
\hline & $40 \sim 49$ & $10(25.0)$ & $13(27.1)$ & \\
\hline & $50 \sim$ & $21(52.5)$ & $10(20.8)$ & $\mathrm{p}<0.01$ \\
\hline & & & & \\
\hline 出身地 & 済州道 & $33(61.0)$ & & \\
\hline \multirow[t]{5}{*}{ 1）配偶者 } & 慶尚道 & $12(22.2)$ & & \\
\hline & 全羅道 & $7(13.0)$ & & \\
\hline & ソウル & $1(1.9)$ & & \\
\hline & 釜山 & $1(1.9)$ & & \\
\hline & 日 本 & & 37 & \\
\hline \multirow[t]{7}{*}{ 2) 主 婦 } & 済州道 & $25(62.5)$ & & \\
\hline & 度尚道 & $9(22.5)$ & & \\
\hline & 全羅道 & $3(7.5)$ & & \\
\hline & ソウル & $1(2.5)$ & & \\
\hline & 江原道 & $1(2.5)$ & & \\
\hline & 釜 山 & $1(2.5)$ & & \\
\hline & 日 本 & & 48 & \\
\hline 在日年数 & $\sim 9$ & $11(27.5)$ & & \\
\hline \multirow[t]{3}{*}{ 主 婦 } & $10 \sim 19$ & $3(7.5)$ & & \\
\hline & $20 \sim 29$ & $7(17.5)$ & & \\
\hline & $30 \sim$ & $19(47.5)$ & & \\
\hline 教育程度 & 無 学 & $5(9.3)$ & $0(0.0)$ & 26.23 \\
\hline \multirow[t]{4}{*}{ 1）配偶指 } & 小学校卒 & $25(46.3)$ & $2(5.4)$ & \\
\hline & 中学校" & $7(13.0)$ & $3(8.1)$ & $\mathrm{p}<0.01$ \\
\hline & 高等学校" & $13(24.1)$ & $21(56.8)$ & \\
\hline & 大学以上" & $4(7.3)$ & $11(29.7)$ & \\
\hline \multirow[t]{5}{*}{ 2) 主 婦 } & 無 学 & $12(30.8)$ & $0(0.0)$ & 24.35 \\
\hline & 小学校卒 & $11(28.2)$ & $9(19.1)$ & \\
\hline & 中学校" & $6(15.4)$ & $19(40.4)$ & $\mathrm{p}<0.01$ \\
\hline & 高等学校" & $6(15.4)$ & $17(36.2)$ & \\
\hline & 大学以上" & $4(10.2)$ & $2(4.3)$ & \\
\hline 職 業 & 銊负師 & $1(1.9)$ & $1(2.7)$ & \\
\hline \multirow[t]{13}{*}{ 1) 配偶者 } & 牧 師 & $2(3.7)$ & $0(0.0)$ & \\
\hline & 会社員 & $5(9.3)$ & $6(16.2)$ & \\
\hline & サンダル加工 & $16(29.6)$ & $2(5.4)$ & \\
\hline & ミシン 加工 & $10(18.5)$ & $5(13.6)$ & \\
\hline & I $\triangle$ 加工 & $1(1.9)$ & $0(0.0)$ & \\
\hline & 皮 革 加工 & $4(7.3)$ & $1(2.7)$ & \\
\hline & 金 属 加工 & $2(3.7)$ & $6(16.2)$ & \\
\hline & 土 木 & $3(5.6)$ & $2(5.4)$ & \\
\hline & 飲食・販賣 & $4(7.3)$ & $3(8.1)$ & \\
\hline & 不動産 業 & $1(1.9)$ & $1(2.7)$ & \\
\hline & 運転 手 & $2(3.7)$ & $6(16.2)$ & \\
\hline & サービス業 & $1(1.9)$ & $2(5.4)$ & \\
\hline & 無職 & $2(3.7)$ & $2(5.4)$ & \\
\hline
\end{tabular}


Table 1-2 世代別生活環境

\begin{tabular}{|c|c|c|c|c|}
\hline 要 因 & カテゴリー & 一 & 二 世 & $\chi^{2 \text { 值 }}$ \\
\hline \multirow[t]{2}{*}{ 2) 主 婦 } & 職業ある & $24(60.0)$ & $35(72.9)$ & 1.65 \\
\hline & "なし & $16(40.0)$ & $13(27.1)$ & $\mathrm{p}>0.05$ \\
\hline \multirow[t]{7}{*}{ 子供数 } & 0 & $2(5.0)$ & $1(2.1)$ & 2.50 \\
\hline & 1 & $7(17.5)$ & $6(12.5)$ & \\
\hline & 2 & $6(15.0)$ & $9(18.8)$ & $p>0.05$ \\
\hline & 3 & $8(20.0)$ & $14(29.2)$ & \\
\hline & 4 & $8(20.0)$ & $11(22.9)$ & \\
\hline & 5 以上 & $9(22.5)$ & $7(14.5)$ & \\
\hline & & $(\bar{X}=3.15 \pm 1.8)$ & $(\bar{X}=3.13 \pm 1.5)$ & \\
\hline \multirow[t]{6}{*}{ 家族数 } & 2 & $4(10.3)$ & $4(8.3)$ & 3.50 \\
\hline & 3 & $9(23.1)$ & $9(18.8)$ & \\
\hline & 4 & $9(23.1)$ & $14(29.2)$ & $\mathrm{p}>0.05$ \\
\hline & 5 & $12(30.8)$ & $9(18.8)$ & \\
\hline & 6 以上 & $5(12.8)$ & $12(25.0)$ & \\
\hline & & $(\bar{X}=4.13 \pm 1.2)$ & $(\bar{X}=4.48 \pm 1.6)$ & \\
\hline \multirow[t]{2}{*}{ 世代構成 } & 配偶者一世 & $22(66.7)$ & $24(57.1)$ & 0.67 \\
\hline & " 二世 & $13(33.3)$ & $18(22.9)$ & $p>0.05$ \\
\hline \multirow[t]{3}{*}{ 家庭内位置 } & 核家族の主婦 & $35(87.5)$ & $41(87.5)$ & 1.09 \\
\hline & 払大家族の嫁 & $3(2.5)$ & $6(8.3)$ & \\
\hline & " " 姑 & $2(5.0)$ & $1(2.1)$ & $p>0.05$ \\
\hline \multirow[t]{3}{*}{ 結婚状況 } & 夫 あり & $39(97.5)$ & $42(87.5)$ & 2.04 \\
\hline & 死別 & $1(2.5)$ & $4(8.3)$ & \\
\hline & 離＼cjkstart婚 & $0(0.0)$ & $2(4.2)$ & $\mathrm{p}>0.05$ \\
\hline \multirow[t]{3}{*}{ 就労期間 } & $\sim 9$ & $12(57.1)$ & $4(20.0)$ & 6.64 \\
\hline & $10 \sim 19$ & $4(19.0)$ & $10(50.0)$ & \\
\hline & $20 \sim$ & $5(23.8)$ & $6(30.0)$ & $\mathrm{p}<0.05$ \\
\hline \multirow[t]{3}{*}{ 生活時間 } & 睡眠時間 & $7.50 \pm 1.25$ & $7.35 \pm 1.08$ & \\
\hline & 労働 "I & $8.54 \pm 1.69$ & $7.94 \pm 2.81$ & \\
\hline & 家事 " & $3.50 \pm 1.50$ & $4.20 \pm 2.03$ & \\
\hline \multirow[t]{4}{*}{ 現在の悩み } & 経済問題 & $13(34.2)$ & $8(17.4)$ & 9.08 \\
\hline & 健康 " & $8(21.1)$ & $3(6.5)$ & \\
\hline & 子供 "I & $7(18.4)$ & $13(28.3)$ & $\mathrm{p}<0.05$ \\
\hline & 別にない & $10(26.3)$ & $22(47.8)$ & \\
\hline \multirow[t]{3}{*}{ 収入の満足度 } & 満 足 & $10(26.3)$ & $15(32.6)$ & 0.61 \\
\hline & 不満足 & $17(44.7)$ & $17(37.0)$ & \\
\hline & 考えたことない & $11(28.9)$ & $14(30.4)$ & $\mathrm{p}>0.05$ \\
\hline
\end{tabular}

以上の在日韓国人の一般生活環境の中から食生 活に影響すると思われる項目を選んで，それらに ついて食品群摂取量の差を検討した。そ項目は 世代，年齢，在日年数である。

\section{2. 調查期間}

1）生活環境の質問票調査

質問票調査は1981年 3 月上旬 5 月下旬にわ たって，筆頭著者が面接聞き取り法で実施した。

2）食物摄取状況調查
食物摂取状況調査は熟練した調査員（栄養士・ 管理栄養士）を多数揄えることができないので, 前・後期の 2 群に分けて下記の期間に実施した。 前期：1981年 5 月11月（月） 5 月15日（金） 後期：1981年 5 月 18 日（月） 5 月 22 日（金）

\section{III 調 査 方 法}

特に食物摂取状況調查は日本の国民栄養調査 (厚生省)の調查方法に準じて実施した. 調查手段 
としては栄養士（調査員）が調査期間中毎日 1 回 は戸別訪問し, 計量法, 記入法を確認しかつ技術 指導をしたので “面接聞き取り法”を補助的に実 施した。な拀，計量に当たっては，あらかじめ， $1 \mathrm{~kg}$ 用台秤と計量用カップ・スプーンを貸与し(調 查終了後これを協力謝礼として贈与す）同一の精 度で秤量したものである。 また, 本調査の方法上 の特色は世帯全体の摂取量と主婦の個人の食物摂 取状況を調査したもので調査票はそのための改良 工夫をした，ただし，本論文では主婦の個人の食 物摂取状況を調査した資料だけを分析した。それ は主婦個人の摂取状況をできるだけ正確に調査す るためには世帯全体の摂取状況も秤量・記録する ことがよいと考えたからである。

\section{IV 統計分析の手法}

本研究で用いた主たる統計手法は以下に示すと
おりである。

1. 食物摂取状況について

食品群別摂取量 ( 1 人 1 日当たりのグラム重量) は, 三訂日本食品標準成分表（科学技術庁1978） を基礎資料として，食品群分類は日本の国民栄養 調查食品群別表を参考にして分類した.すなわち, 米, パン, めん類, その他の殼類, いも類, 砂糖 類, 菓子類, 油脂類, 豆·豆製品, 魚介類, 肉類, 卵類，乳·乳製品，緑黄色野菜，その他の野菜(以 下淡色野菜とする), 果実類, 海草類, 嗜好飲料, 酒類, 調味料, 加工食品抢よび特にキムチ類を加 えた22食品群に分類して集計した。そして各食品 群を世代，年齢，在日年数によって分析，その值 の有意性を調べた。検定は T-検定, 二元配置分散 分析を行なった。

Table 2 The difference of food intake (g.) of the groups by generation

\begin{tabular}{|c|c|c|c|c|c|c|c|c|}
\hline & \multirow{3}{*}{ Food Groups } & \multicolumn{4}{|c|}{ Generation } & \multirow{2}{*}{\multicolumn{3}{|c|}{ Total (88) }} \\
\hline & & \multicolumn{2}{|c|}{ First (40) } & \multicolumn{2}{|c|}{ Second (48) } & & & \\
\hline & & Mean & S.D. & Mean & S.D. & Mean & S.D. & C.V.(\%) \\
\hline & Rice & 194.6 & 90.8 & 195.6 & 85.5 & 195.1 & 87.4 & 44.8 \\
\hline 2. & Bread & 65.0 & 69.4 & 54.9 & 56.2 & 59.5 & 62.4 & 104.9 \\
\hline 3. & Noodles & 7.3 & 18.1 & 28.4 & $40.0^{* *}$ & 18.8 & 33.5 & 178.2 \\
\hline & Other Cereals & 4.7 & 11.2 & 3.2 & 8.4 & 3.9 & 9.8 & 251.3 \\
\hline & Potatoes & 24.3 & 33.7 & 28.0 & 33.5 & 26.3 & 33.4 & 127.0 \\
\hline & Sugar & 9.2 & 9.4 & 10.0 & 8.3 & 9.7 & 8.8 & 90.7 \\
\hline & Confectioneries & 16.4 & 25.5 & 22.7 & 39.7 & 19.8 & 33.9 & 171.2 \\
\hline & Oil and Fats & 13.8 & 10.1 & 12.7 & 9.8 & 13.2 & 9.9 & 75.0 \\
\hline & Pulses & 74.9 & 67.9 & 60.6 & 49.3 & 67.1 & 58.6 & 87.3 \\
\hline 10. & Fish & 70.2 & 41.7 & 88.7 & 54.8 & 80.3 & 49.8 & 62.0 \\
\hline 11. & Meats & 74.3 & 70.0 & 84.6 & 43.3 & 79.9 & 56.9 & 71.2 \\
\hline 12. & Eggs & 19.4 & 24.9 & 28.3 & 30.8 & 24.2 & 28.5 & 117.8 \\
\hline 13. & Milk & 79.7 & 120.5 & 79.7 & 108.5 & 79.7 & 113.4 & 142.3 \\
\hline 14. & Green Vegetables & 71.0 & 59.3 & 56.1 & 40.3 & 62.9 & 50.0 & 79.5 \\
\hline 15. & Other Vegetables & 206.1 & 129.7 & 233.6 & 128.4 & 221.1 & 129.0 & 58.3 \\
\hline 16. & Fruits & 100.8 & 126.5 & 87.2 & 92.5 & 93.4 & 108.8 & 116.5 \\
\hline & Seaweeds & 3.2 & 4.2 & 3.5 & 5.9 & 3.4 & 5.2 & 152.9 \\
\hline & Beverages & 2.2 & 3.9 & 3.2 & 4.1 & 2.8 & 4.0 & 142.9 \\
\hline 19. & Alcohols & 0.0 & 0.0 & 21.2 & 70.7 & 11.6 & 53.1 & 457.8 \\
\hline 20. & Seasonings & 27.9 & 17.4 & 43.9 & $25.6^{* * *}$ & 36.6 & 23.5 & 64.2 \\
\hline & Kimchies & 49.2 & 54.5 & 24.1 & $28.7^{* *}$ & 35.5 & 44.0 & 123.9 \\
\hline 22. & Processed Food & 31.2 & 48.7 & 35.1 & 51.5 & 33.3 & 50.0 & 150.2 \\
\hline
\end{tabular}

**; $p<0.01^{* * *} ; p<0.001$ 


\section{V 結 果}

1. 食品群別摂取量

1）世代間の比較

食品群別摂取量 ( 1 人 1 日当たりのグラム重量) については22食品群別に集計してそれぞれの平均 摂取量の平均値，標準偏差，変動係数を求めた。 その結果は Table 2 に示す. 全体としての変動係 数に注目すると米, 油脂類, 魚介類, 肉類, 緑黄 色野菜, 淡色野菜, 調味料などは变動係数が小さ いので，これらの食品は対象となった在日韓国婦 人の間で格差の小さい摂取のされ方をしている. パン, いも類, 砂糖類, 豆・豆製品, 卵類, 果実 類, キムチ類の変動係数は $100 \%$ 前後を取り，それ 以外の食品は変動係数が大きく, 個人間の格差が 食生活環境や嗜好，食習慣などによって大きい食 品であると考えられる。

次に食品摂取状況を世代別に分けて見ると，一
世と二世の間で有意差が認められる食品はめん 類, 調味料, キムチ類であり, めん類, 調味料は 二世に多く，キムチ類は一世に多かった。特に酒 類は一世ではほとんど飲んでいないことが注目さ れる。この対象者の特徵は嗜好飲料はほとんどが コーヒーであり, 加工食品を多く摄取しているこ とである。

2）年齢・世代別の比較

対象を39歳以下の群，40４9歳群，そして50歳 以上の年龄階層別・世代別に分けて摄取状況を比 較した結果はTable 3 に示された。 まず一元配置 法で年齢階層間の格差を分析して見ると統計的有 意差がある食品はない，次に各年齢階層をさらに 世代別に分けてそれぞれの差について下-検定を すると40４9歳階層だけに肉類，調味料，キムチ 類の統計的有意差が認められる。すなわち肉類, 調味料は二世に, キムチ類は一世に多く摄取され ている。

Table 3 The difference of food intake (g.) of the groups by age

\begin{tabular}{|c|c|c|c|c|c|c|c|c|c|c|c|c|}
\hline \multirow{3}{*}{ Food Groups } & \multicolumn{4}{|c|}{ Below 39 years } & \multicolumn{4}{|c|}{$40-49$ years } & \multicolumn{4}{|c|}{ Above 50 years } \\
\hline & \multicolumn{2}{|c|}{ First (9) } & \multicolumn{2}{|c|}{ Second (25) } & \multicolumn{2}{|c|}{ First (10) } & \multicolumn{2}{|c|}{ Second (13) } & \multicolumn{2}{|c|}{ First (21) } & \multicolumn{2}{|c|}{ Second $(10)$} \\
\hline & Mean & S.D. & Mean & S.D. & Mean & S.D. & Mean & S.D. & Mean & S.D. & Mean & S.D. \\
\hline 1. Rice & 181.8 & 128.2 & 208.7 & 77.2 & 213.9 & 85.1 & 201.4 & 109.4 & 190.8 & 77.2 & 155.2 & 63.0 \\
\hline 2. Bread & 54.5 & 60.1 & 49.9 & 50.3 & 62.6 & 50.8 & 60.0 & 44.8 & 70.7 & 81.9 & 60.6 & .83 .1 \\
\hline 3. Noodles & 15.3 & 32.8 & 31.8 & 43.8 & 3.1 & 8.7 & 28.1 & 41.6 & 5.8 & 11.7 & 20.4 & 28.7 \\
\hline 4. Other Cereals & 8.4 & 15.3 & 3.1 & 8.4 & 5.1 & 13.7 & 2.4 & 6.3 & 2.8 & 7.7 & 4.4 & 11.0 \\
\hline 5. Potatoes & 34.1 & 48.6 & 32.0 & 32.4 & 20.7 & 28.0 & 17.7 & 28.5 & 21.8 & 29.4 & 31.4 & 41.9 \\
\hline 6. Sugar & 8.4 & 5.9 & 9.8 & 7.0 & 9.9 & 8.9 & 13.1 & 10.7 & 9.3 & 11.0 & 6.5 & 6.7 \\
\hline 7. Confectioneries & 25.7 & 23.9 & 23.1 & 46.7 & 28.3 & 37.7 & 27.9 & 36.3 & 6.7 & 14.0 & 14.9 & 23.1 \\
\hline 8. Oil and Fats & 17.3 & 11.2 & 12.0 & 9.6 & 10.6 & 6.8 & 15.5 & 12.1 & 13.8 & 10.9 & 10.6 & 6.9 \\
\hline 9. Pulses & 89.1 & 98.2 & 59.4 & 43.7 & 61.3 & 26.2 & 57.1 & 44.7 & 75.4 & 68.2 & 68.1 & 69.5 \\
\hline 10. Fish & 72.7 & 53.9 & 92.2 & 64.3 & 60.4 & 18.7 & 88.2 & 45.3 & 73.9 & 44.7 & 80.5 & 42.5 \\
\hline 11. Meats & 124.7 & 114.2 & 83.6 & 45.1 & 50.5 & 31.2 & 94.7 & $46.3^{*}$ & 63.9 & 48.6 & 74.1 & 34.8 \\
\hline 12. Eggs & 17.3 & 24.2 & 27.3 & 32.7 & 26.8 & 36.9 & 33.6 & 33.5 & 16.8 & 18.0 & 23.6 & 23.1 \\
\hline 13. Milk & 125.4 & 165.8 & 76.6 & 93.2 & 71.9 & 95.1 & 65.6 & 85.4 & 63.8 & 109.5 & 105.8 & 166.0 \\
\hline 14. Green Vegetables & 63.7 & 56.1 & 54.8 & 34.8 & 68.3 & 48.7 & 63.0 & 46.7 & 75.4 & 67.0 & 50.4 & 47.9 \\
\hline 15. Other Vegetables & 216.5 & 120.6 & 220.7 & 117.2 & 153.1 & 84.3 & 206.6 & 94.1 & 226.6 & 148.0 & 300.7 & 176.6 \\
\hline 16. Fruits & 167.0 & 158.7 & 78.0 & 92.3 & 81.8 & 103.5 & 82.7 & 87.0 & 81.5 & 117.3 & 116.1 & 103.4 \\
\hline 17. Seaweeds & 4.6 & 6.9 & 2.8 & 5.4 & 3.6 & 4.3 & 4.0 & 5.8 & 2.5 & 2.2 & 4.3 & 7.5 \\
\hline 18. Beverages & 3.7 & 6.2 & 2.9 & 3.9 & 2.4 & 3.8 & 3.4 & 4.3 & 1.5 & 2.6 & 3.9 & 4.5 \\
\hline 19. Alcohols & 0.0 & 0.0 & 28.6 & 88.8 & 0.0 & 0.0 & 0.2 & 0.6 & 0.0 & 0.0 & 30.0 & 64.8 \\
\hline 20. Seasonings & 34.4 & 22.5 & 47.0 & 29.2 & 22.1 & 11.5 & 42.4 & $16.3^{* *}$ & 27.9 & 17.0 & 38.1 & 26.8 \\
\hline 21. Kimchies & 28.9 & 19.5 & 28.2 & 28.3 & 75.9 & 55.6 & 17.7 & $30.9^{* *}$ & 45.2 & 60.8 & 22.1 & 28.0 \\
\hline 22. Processed Food & 43.2 & 52.6 & 29.1 & 48.2 & 12.7 & 17.8 & 35.2 & 45.9 & 34.8 & 55.9 & 49.8 & 67.2 \\
\hline
\end{tabular}


Table 4 The difference of food intake (g.) of the groups by residential duration

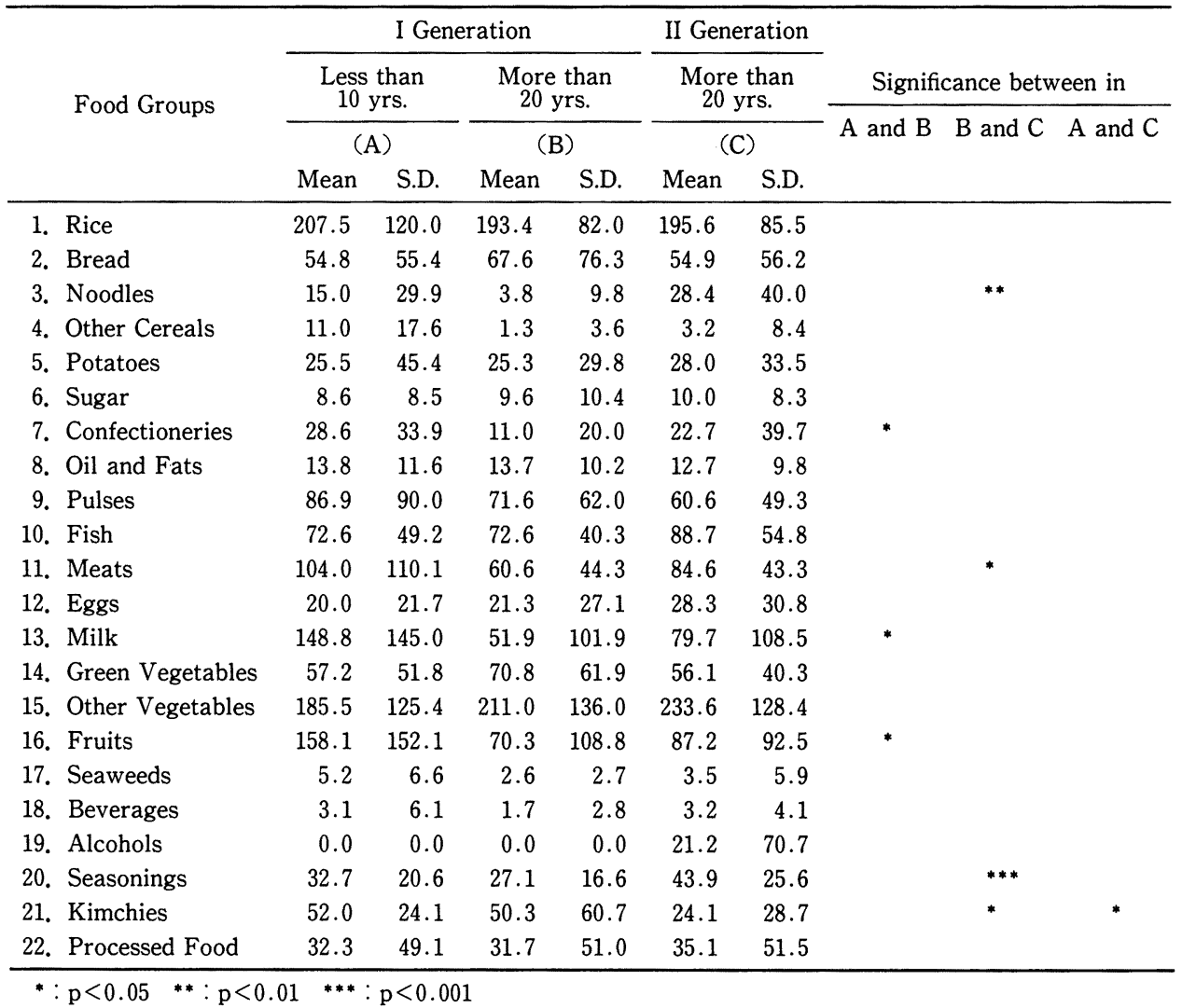

3）在日年数・世代別の比較

日本に住む年数の長短別による食品摂取量の相 違を 10 年末満の群と 20 年以上の群に分けて比較す ると Table 4 に示す結果が得られた。 まず一世群 で10年末満の群 (A) と20年以上の群 (B) の間を 比較して, $\mathrm{A}$ 群に有意に多い食品は菓子類, 乳・ 乳製品，果実類である。そして10年末満の群 (A) と二世 $(\mathrm{C})$ 一すずて 20 年以上の居住年数を持っ ているが——比較して，有意差があった食品は キムチ類だけであり，それは $\mathrm{A}$ 群に多い. 次に $\mathrm{B}$ 群と C 群を比較して, C 群に有意に多い食品はめ ん類, 肉類, 調味料であり, $\mathrm{B}$ 群に有意に多い食 品はキムチ類だけである。在日年数が 10 年末満の 群を韓国に住む韓国人（1980年度国民栄養調査成 績，都市世帯の平均値）に較べて，摂取量が少な い傾向を示す食品は米, その他の穀類, キム千類
である，因に，韓国の栄養調査成績は標準偏差を 付記していないので統計的に母平均の差を検定す ることはできない，また，逆に著しく多い傾向が 見られる食品は砂糖, 肉類, 乳・乳製品, 果実類 などである。このことは在日年数があまり長く経 過しない間は, 日本の豊かな生活環境にすぐ適応 して主食としての米をへらしながら扔かずの量と 種類が増兄，そして在日年数が長くなると加齢に よって摄取量が減少する中で, 韓国的食品だと自 分なりに思う食品を継承しながら，いっぽう日本 で容易に入手できる食品を増加させるという傾向 がある。

\section{2. 熱量と栄養素摄取量}

熱量と栄養素の摂取量は三訂日本標準食品成分 表（科学技術庁1978）を用いまたこれに記載さ れていないキム千類等については韓国食品成分表 
Table 5 The difference of nutrient intake of the groups by generation

\begin{tabular}{|c|c|c|c|c|c|c|c|}
\hline \multirow{3}{*}{ Nutrient } & \multicolumn{4}{|c|}{ Generation } & \multirow{2}{*}{\multicolumn{2}{|c|}{ Total (88) }} & \multirow{3}{*}{ R.D.A.* } \\
\hline & \multicolumn{2}{|c|}{ First (40) } & \multicolumn{2}{|c|}{ Second (48) } & & & \\
\hline & Mean & S.D. & Mean & S.D. & Mean & S.D. & \\
\hline Energy (kcal) & 1828.9 & 489.4 & 1957.3 & 597.9 & 1898.9 & 552.0 & 1900.0 \\
\hline \multicolumn{8}{|l|}{ Protein } \\
\hline Total, $\mathrm{g}$ & 73.2 & 25.3 & 78.9 & 25.0 & 76.3 & 25.1 & 60.0 \\
\hline Animal, $\mathrm{g}$ & 35.1 & & 40.3 & & 38.0 & & \\
\hline \multicolumn{8}{|l|}{ Fat } \\
\hline Total, $\mathrm{g}$ & 42.2 & 20.4 & 51.4 & 26.6 & 47.2 & 24.3 & \\
\hline Animal, $\mathrm{g}$ & 21.2 & & 28.3 & & 24.9 & & \\
\hline Carbohydrate, $\mathrm{g}$ & 281.4 & 85.9 & 285.9 & 89.2 & 283.9 & 87.2 & \\
\hline Calcium, mg & 479.8 & 310.9 & 487.6 & 279.1 & 484.1 & 288.1 & 600.0 \\
\hline Iron, mg & 13.1 & 5.1 & 13.8 & 5.0 & 13.5 & 5.0 & 10.0 \\
\hline Vitamin A, IU & 1880.9 & 834.6 & 1545.2 & 902.1 & 1697.8 & 883.2 & 1800.0 \\
\hline Thaiamin, mg & 1.00 & 0.32 & 1.17 & 0.72 & 1.09 & 0.58 & 0.8 \\
\hline Riboflabin, mg & 1.05 & 0.45 & 1.13 & 0.61 & 1.09 & 0.54 & 1.0 \\
\hline Ascorbic acid, mg & 105.3 & 61.1 & 98.3 & 49.4 & 101.5 & 54.8 & 50.0 \\
\hline Cereals/Energy（\%） & 49.1 & & 46.7 & & 47.7 & & \\
\hline $\begin{array}{l}\text { Animal protein } \\
\text { ratio }(\%)\end{array}$ & 48.0 & & 51.1 & & 49.8 & & \\
\hline
\end{tabular}

* : Recommended Dietary Allowances for Japaneses (1979).

（農村振興庁1980)を用いて計算した。その結果は Table 5 に示す。摄取熱量は1898.9 $\pm 552.0 \mathrm{kcal}$ であり, 日本人の栄養所要量（厚生省公衆衛生局 1979）に比較して低值である。栄養素については 在日韓国婦人の栄養摂取量は日本人の栄養所要量 に比べてカルシウム,ビタミン A が低值である. 世代別に比べると一世より二世が多く摂ってい る.ただし，年齢・労作量等については今後, 検 討する必要がある。

\section{3. 食物消費構造}

日常生活における食物摄取の状況には食品群な いし食品が拉いに密接な係わりを保って扣り， あるものは補完的な結びつきがあり，あるものは 排他的に競合することがわかっている，それらの 補完・競合の関係を数量的に示すために, 各食品 群の摂取量を変量とする食品群間の相関係数を相 関行列として示す。この相関係数行列は食物消費 構造と呼ばれるものである。その結果は Table 6 に示す，米を中心に正相関がある食品群，すなわ ち米に対して補完的な関係がある食品群はいも類 $(r=0.183)$ ，豆・豆製品 $(r=0.194) ，$ キムチ $(r=$
0.205)があり, 米に対して負の相関がある食品群 は，パン $(\mathrm{r}=-0.238)$, めん類 $(\mathrm{r}=-0.216)$ で ある。一方，米に対して強い逆相関をもつパンに 対して, 正の相関関係をもつものは油脂類 $(r=$ $0.217)$, 加工食品 $(r=0.213)$ であり, 負の相関関 係をもつものは米のほかには, その他の穀類 $(\mathrm{r}=$ 0.194)がある。 めん類に対して正の相関関係をむ つものは調味料 $(\mathrm{r}=0.228)$, 加工食品 $(\mathrm{r}=0.189)$ があり, 負の相関関係をもつものは米のほかに, 油脂類 $(r=-0.194)$, 緑黄色野菜 $(r=-0.282)$, キムチ類 $(r=0.215)$ がある。その他の食品群につ いて見ると，いも類は豆・豆製品 $(r=0,248)$, 魚 介類 $(r=0.256)$, 乳・乳製品 $(r=0.258)$, 緑黄色 野菜 $(\mathrm{r}=0.200)$, 果実類 $(r=0.280)$, 調味料 $(r=$ $0.254)$ に対し強い補完性がある。また，砂糖類は 喈好飲料 $(r=0.307)$ と正の相関があり，豆・豆製 品 $(r=-0.243)$, 乳・乳製品 $(r=-0.215)$ に対 しては負の相関がある。油脂類はパンのほかに 豆・豆製品 $(r=0.178)$, 卵類 $(r=0.473)$, 緑黄色 野菜 $(r=0.422)$, 淡色野菜 $(r=0.314)$, 果実類 $(r=$ $0.202)$, 海草類 $(r=0.215)$ に対して強い補完性が 
Table 6 Food consumption structure, Korean women in Japan (Correlation matrix)

\begin{tabular}{|c|c|c|c|c|c|c|c|c|c|c|}
\hline \multicolumn{11}{|l|}{ Food Groups } \\
\hline • Rice & 1.000 & & & & & & & & & \\
\hline - Bread & $-.238^{*}$ & 1.000 & & & & & & & & \\
\hline - Noodles & $-.216^{*}$ & -.024 & 1.000 & & & & & & & \\
\hline - Other Cereals & .143 & $-.194^{*}$ & .028 & 1.000 & & & & & & \\
\hline - Potatoes & $.183^{*}$ & .040 & -.127 & .179 & 1.000 & & & & & \\
\hline - Sugar & -.037 & .001 & -.025 & -.144 & -.071 & 1.000 & & & & \\
\hline - Confectioneries & .081 & -.074 & -.053 & -.049 & -.032 & .120 & 1.000 & & & \\
\hline - Oil and Fats & -.099 & $.217^{*}$ & $-.194^{*}$ & -.005 & .071 & -.116 & -.048 & 1.000 & & \\
\hline - Pulses & $.194^{*}$ & -.085 & -.056 & $.227^{*}$ & $.248^{* *}$ & $-.243^{*}$ & -.044 & $.178^{*}$ & 1.000 & \\
\hline - Fish & .131 & .055 & -.139 & .071 & $.256^{* *}$ & -.097 & -.037 & .132 & $.357^{* *}$ & 1.000 \\
\hline - Meats & .054 & -.009 & .030 & .054 & -.069 & .055 & $.227^{* *}$ & .077 & .229 & .020 \\
\hline - Eggs & .080 & .119 & .013 & .049 & .136 & -.080 & -.104 & $.473^{* * *}$ & $.188^{*}$ & .125 \\
\hline · Milk & .109 & -.021 & -.057 & $.249^{* *}$ & $.258^{* *}$ & $-.215^{*}$ & .136 & .129 & $.372^{* * *}$ & .161 \\
\hline - Green Vegetables & .127 & .055 & $-.282^{* *}$ & -.004 & $.200^{*}$ & -.144 & .087 & $.422^{* * *}$ & .038 & .139 \\
\hline - Other Vegetables & .107 & -.079 & .043 & .075 & .123 & -.107 & .094 & $.314^{* *}$ & .140 & .060 \\
\hline - Fruits & .017 & .165 & -.022 & $.255^{*}$ & $.280^{* *}$ & -.132 & .081 & $.202^{*}$ & $.285^{* *}$ & .162 \\
\hline - Seaweeds & .072 & -.085 & -.112 & $.181^{*}$ & .150 & -.006 & -.067 & $.215^{*}$ & .209 & $.268^{* *}$ \\
\hline - Beverages & -.045 & -.016 & -.131 & .096 & -.071 & $.307^{* *}$ & .044 & -.027 & $-.369^{* * *}$ & .111 \\
\hline - Seasonings & .095 & -.013 & $.228^{*}$ & .160 & $.254^{* *}$ & -.025 & .063 & .142 & $.286^{* *}$ & .205 \\
\hline - Kimchies & $.205^{*}$ & -.016 & $-.215^{*}$ & -.095 & -.125 & .054 & .051 & -.090 & -.024 & -.119 \\
\hline \multirow[t]{2}{*}{ - Processed Food } & -.039 & $.213^{*}$ & $.189^{*}$ & -.109 & .001 & -.087 & -.049 & -.103 & $-.183^{*}$ & -.158 \\
\hline & 1. & 2. & 3. & 4. & 5. & 6. & 7. & 8. & 9. & 10. \\
\hline - Meats & 1.000 & & & & & & & & & \\
\hline · Eggs & .035 & 1.000 & & & & & & & & \\
\hline • Milk & $.205^{*}$ & .136 & 1.000 & & & & & & & \\
\hline - Green Vegetables & .119 & .080 & $.181^{*}$ & 1.000 & & & & & & \\
\hline - Other Vegetables & .132 & .109 & $.234^{*}$ & $.352^{* * *}$ & 1.000 & & & & & \\
\hline - Fruits & .074 & .035 & $.430^{* * *}$ & $.230^{*}$ & .282 & 1.000 & & & & \\
\hline - Seaweeds & .144 & $.254^{* *}$ & $.228^{*}$ & .170 & .011 & .046 & 1.000 & & & \\
\hline - Beverages & -.080 & -.111 & $-.225^{*}$ & -.105 & $-.187^{*}$ & -.072 & -.034 & 1.000 & & \\
\hline - Seasonings & $.280^{* *}$ & $.410^{* * *}$ & $.240^{*}$ & .068 & .113 & $.247^{*}$ & $.240^{*}$ & -.071 & 1.000 & \\
\hline · Kimchies & -.120 & .032 & -.083 & -.014 & -.162 & -.116 & -.033 & .016 & -.186 & 1.000 \\
\hline \multirow[t]{2}{*}{ - Processed Food } & -.061 & -.027 & .013 & -.132 & $: 020$ & .044 & -.013 & -.081 & .052 & $-.187^{*}$ \\
\hline & 11. & 12. & 13. & 14. & 15. & 16. & 17. & 18. & 19. & 20. \\
\hline
\end{tabular}

ある。そして豆・豆製品は米，その他の穀類，い も類のほかに魚介類 $(\mathrm{r}=0.357)$, 卵類 $(\mathrm{r}=0.188)$, 乳・乳製品 $(r=0.372)$, 果実類 $(r=0.258)$, 調味 料 $(r=0.286)$ に対して強い補完性があり, 砂糖の ほかに嗜好飲料 $(r=-0.369)$, 加工食品 $(r=$ $-0.183)$ に対して負の相関がある．魚介類はいも 類, 豆・豆製品のほかに海草類 $(r=0.268)$, 肉類 は菓子類のほかに乳・乳製品 $(r=0.205)$, 調味料 $(\mathrm{r}=0.280)$ に対して強い補完性がある。即類は油 脂類, 豆・豆製品のほかに海草類 $(r=0.254)$, 調 味料 $(r=0.410)$ ，そして乳・乳製品はその他の穀
類，いも類，豆・豆製品，肉類のほかに緑黄色野 菜 $(r=0.181)$, 淡色野菜 $(r=0.234)$, 果実類 $(r=$ $0.430)$, 海草類 $(r=0.228)$, 調味料 $(r=0.240)$ に対して強い補完性があり, 砂糖類, 嗜好领料 $(\mathrm{r}=-0.225)$ に対して負の相関がある，緑黄色野 菜はいも類, 油脂類のほかに淡色野菜 $(\mathrm{r}=0.352)$, 果実類 $(r=0.230)$ に対して，また淡色野菜は油脂 類, 豆・豆製品, 乳・乳製品, 緑黄色野菜のほか に調味料 $(r=0.247)$ に対していずれも強に補完性 がある。海草類は油脂類, 魚介類, 卵類, 乳・乳 製品のほかに調味料 $(r=0.240)$ に対して強い補完 
Table 7 Food consumption structure, First generation Korean women in Japan (Correlation matrix) Food Groups

\begin{tabular}{|c|c|c|c|c|c|c|c|c|c|c|}
\hline • Rice & 1.000 & & & & & & & & & \\
\hline - Bread & $-.279^{*}$ & 1.000 & & & & & & & & \\
\hline - Noodles & $-.060^{*}$ & .115 & 1.000 & & & & & & & \\
\hline - Other Cereals & .148 & .227 & .164 & 1.000 & & & & & & \\
\hline - Potatoes & .190 & -.066 & -.089 & .149 & 1.000 & & & & & \\
\hline - Sugar & .024 & .167 & -.032 & -.213 & -.179 & 1.000 & & & & \\
\hline - Confectioneries & .144 & -.163 & -.098 & .127 & -.023 & .142 & 1.000 & & & \\
\hline - Oil and Fats & -.186 & .151 & .037 & -.058 & $.422^{* *}$ & -.233 & .031 & 1.000 & & \\
\hline - Pulses & .239 & -.148 & -.143 & .084 & $.367^{* *}$ & -.143 & .026 & .182 & 1.000 & \\
\hline • Fish & -.137 & .106 & -.064 & .030 & .232 & .024 & -.036 & $.376^{* *}$ & $.594^{* * *}$ & 1.000 \\
\hline - Meats & -.029 & .034 & -.001 & .140 & .041 & .051 & .195 & .070 & $.328^{*}$ & .137 \\
\hline • Eggs & .043 & .109 & .123 & -.059 & $.455^{* *}$ & -.139 & -.139 & $.316^{*}$ & .168 & $.271^{*}$ \\
\hline · Milk & .123 & .032 & -.064 & .211 & $.386^{* *}$ & -.192 & .061 & .106 & $.532^{* * *}$ & $.286^{*}$ \\
\hline - Green Vegetables & -.004 & -.012 & -.164 & .021 & $.321^{*}$ & -.184 & .073 & $.545^{* * *}$ & -.039 & .069 \\
\hline - Other Vegetables & .035 & -.035 & .126 & -.055 & .257 & -.136 & .121 & $.472^{* *}$ & .122 & .014 \\
\hline - Fruits & .174 & .001 & .183 & $.388^{* *}$ & $.435^{* *}$ & -.247 & .137 & .258 & $.401^{*}$ & .180 \\
\hline - Seaweeds & .096 & -.187 & -.025 & $.346^{*}$ & $.287^{*}$ & -.097 & .197 & .252 & $.333^{*}$ & $.469^{* *}$ \\
\hline - Beverages & -.056 & .031 & -.136 & $.278^{*}$ & -.241 & .134 & .099 & -.084 & $-.298^{* * *}$ & -.061 \\
\hline - Seasonings & .234 & -.079 & .119 & .078 & $.505^{* * *}$ & $-.265^{*}$ & -.014 & $.314^{*}$ & $.493^{* *}$ & $.389^{*}$ \\
\hline · Kimchies & .144 & -.028 & $-.136^{*}$ & -.089 & -.125 & .141 & .003 & -.185 & -.077 & -.161 \\
\hline \multirow[t]{2}{*}{ - Processed Food } & .190 & .202 & .248 & .081 & -.235 & -.142 & -.188 & -.061 & -.234 & -.115 \\
\hline & 1. & 2. & 3. & 4. & 5. & 6. & 7. & 8. & 9. & 10. \\
\hline - Meats & 1.000 & & & & & & & & & \\
\hline · Eggs & -.037 & 1.000 & & & & & & & & \\
\hline • Milk & $.424^{* *}$ & .056 & 1.000 & & & & & & & \\
\hline - Green Vegetables & .082 & -.106 & -.003 & 1.000 & & & & & & \\
\hline - Other Vegetables & .117 & .182 & -.007 & $.503^{* * *}$ & 1.000 & & & & & \\
\hline - Fruits & .208 & .063 & $.533^{* * *}$ & .198 & $.299^{*}$ & 1.000 & & & & \\
\hline - Seaweeds & $.387^{*}$ & .110 & $.416^{* *}$ & .231 & .067 & .186 & 1.000 & & & \\
\hline - Beverages & -.136 & -.207 & -.241 & -.113 & $-.275^{*}$ & -.123 & -.166 & 1.000 & & \\
\hline - Seasonings & $.476^{* *}$ & $.316^{*}$ & $.541^{* * *}$ & .125 & .200 & $.351^{*}$ & $.375^{*}$ & -.234 & 1.000 & \\
\hline - Kimchies & -.163 & .109 & -.102 & -.152 & -.058 & -.212 & -.094 & .079 & -.140 & 1.000 \\
\hline \multirow[t]{2}{*}{ - Processed Food } & -.005 & -.026 & -.123 & -.212 & -.072 & .023 & -.015 & .127 & -.004 & -.197 \\
\hline & 11. & 12. & 13. & 14. & 15. & 16. & 17. & 18. & 19. & 20. \\
\hline
\end{tabular}

$* ; p<0.05^{* *} ; p<0.011^{* * *} ; p<0.001$.

性がある．以上述べた食品群間の相互関係以外に もすべての食品群間に何らかの相互関係があっ て，食品群が独立して摂取されるものではないこ とが考えられ，それらを総括して，在日韓国婦人 の食生活上の食物消費構造であるといえる。さら に，世代別に食物消費構造を計算すると，そこに は Table 7, Table 8 に示すように微妙な変化な いし差が存在していることがわかる。一世の場合 では, いも類は油脂類 $(r=0.422)$, 豆・豆製品 $(r=$ $0.367)$, 卵類 $(r=0.455)$, 乳・乳製品 $(r=0.386)$, 緑黄色野菜 $(r=0.321)$, 果実類 $(r=0,435)$, 海草
類（ $\mathrm{r}=0.287 ）$, 調味料 $(\mathrm{r}=0.505)$ と強い補完性 があるのに，二世の場合は魚介類 $(\mathrm{r}=0.266)$ だけ 補完性がある。また，油脂類について見ると，一 世の場合ではいも類のほかに魚介類 $(\mathrm{r}=0.376)$, 卵類 $(r=0.316)$, 緑黄色野菜 $(r=0.545)$, 淡色野 菜 $(\mathrm{r}=0.472)$, 調味料 $(\mathrm{r}=0.314)$ と強い補完性 があるのに，二世の場合はパン $(\mathrm{r}=0.282)$, 卵類 $(\mathrm{r}=0.613)$, 緑黄色野菜 $(\mathrm{r}=0.275)$ に対して補完 性がある。そして豆・豆製品についても見ると， 一世の場合ではいも類のほかに魚介類（r= $0.594)$, 肉類 $(r=0.328)$, 乳・乳製品 $(r=0.532)$, 
Table 8 Food consumption structure, Second generation Korean women in Japan

Food Groups

\begin{tabular}{|c|c|c|c|c|c|c|c|c|c|c|}
\hline • Rice & 1.000 & & & & & & & & & \\
\hline - Bread & -.195 & 1.000 & & & & & & & & \\
\hline - Noodles & $-.321^{*}$ & -.050 & 1.000 & & & & & & & \\
\hline - Other Cereals & .141 & $-.168^{*}$ & .011 & 1.000 & & & & & & \\
\hline - Potatoes & .176 & .159 & -.190 & .228 & 1.000 & & & & & \\
\hline - Sugar & -.098 & -.183 & -.050 & -.051 & .026 & 1.000 & & & & \\
\hline - Confectioneries & .049 & -.010 & -.086 & -.168 & -.048 & .109 & 1.000 & & & \\
\hline - Oil and Fats & -.019 & $.282^{* *}$ & $-.290^{*}$ & .046 & -.226 & .001 & -.086 & 1.000 & & \\
\hline - Pulses & .148 & -.023 & .042 & $.430^{* * *}$ & .138 & $-.368^{*}$ & -.080 & .165 & 1.000 & \\
\hline - Fish & $.315^{*}$ & .048 & $-.260^{*}$ & .141 & $.266^{*}$ & -.205 & -.064 & -.003 & $.243^{*}$ & 1.000 \\
\hline - Meats & .175 & -.061 & .002 & -.079 & -.235 & .055 & $.286^{*}$ & .105 & .087 & -.133 \\
\hline · Eggs & .180 & .160 & -.089 & .174 & -.089 & -.051 & -.114 & $.613^{* * *}$ & $.269^{*}$ & .010 \\
\hline • Milk & .096 & -.081 & -.066 & $.299^{*}$ & .141 & -.240 & .189 & .151 & .179 & .083 \\
\hline - Green Vegetables & $.307^{*}$ & .127 & $-.363^{* *}$ & -.076 & .083 & -.079 & .140 & $.275^{*}$ & .121 & $.284^{*}$ \\
\hline - Other Vegetables & .172 & -.109 & -.035 & $.244^{*}$ & -.001 & -.091 & .068 & .193 & .198 & .058 \\
\hline - Fruits & -.171 & $.384^{* *}$ & -.100 & .043 & .119 & .020 & .062 & .136 & .091 & .190 \\
\hline - Seaweeds & .059 & -.015 & -.154 & .073 & .071 & .052 & -.170 & .201 & .138 & .180 \\
\hline - Beverages & -.038 & -.043 & -.214 & -.075 & .052 & $.463^{* * *}$ & -.002 & .033 & $-.437^{* * *}$ & -.188 \\
\hline - Seasonings & .021 & .083 & .141 & $.309^{*}$ & .113 & .098 & .050 & .094 & $.281^{*}$ & .053 \\
\hline • Kimchies & $.358^{*}$ & -.069 & -.200 & -.196 & -.111 & -.053 & .186 & -.003 & -.003 & .022 \\
\hline \multirow[t]{2}{*}{ - Processed Food } & -.230 & .236 & .178 & -.136 & .183 & -.042 & .014 & -.134 & -.129 & -.201 \\
\hline & 1. & 2. & 3. & 4. & 5. & 6. & 7. & 8. & 9. & 10. \\
\hline - Meats & 1.000 & & & & & & & & & \\
\hline • Eggs & .086 & 1.000 & & & & & & & & \\
\hline • Milk & -.110 & .202 & 1.000 & & & & & & & \\
\hline - Green Vegetables & .239 & $.323^{*}$ & $.439^{* * *}$ & 1.000 & & & & & & \\
\hline - Other Vegetables & .139 & .034 & $.465^{* * *}$ & .229 & 1.000 & & & & & \\
\hline - Fruits & -.155 & .031 & $.284^{*}$ & $.268^{*}$ & $.290^{*}$ & 1.000 & & & & \\
\hline - Seaweeds & -.066 & $.322^{*}$ & .115 & .150 & -.026 & -.059 & 1.000 & & & \\
\hline - Beverages & -.043 & -.087 & -.225 & -.061 & -.146 & -.002 & .036 & 1.000 & & \\
\hline - Seasonings & .124 & $.417^{* *}$ & .089 & .147 & .015 & $.266^{*}$ & .196 & -.067 & 1.000 & \\
\hline - Kimchies & .065 & .062 & -.067 & .155 & $-.279^{*}$ & .009 & .039 & .029 & -.081 & 1.000 \\
\hline \multirow[t]{2}{*}{ - Processed Food } & -.146 & -.039 & .131 & -.037 & .086 & .074 & -.014 & $-.249^{*}$ & .065 & -.189 \\
\hline & 11. & 12. & 13. & 14. & 15. & 16. & 17. & 18. & 19. & 20. \\
\hline
\end{tabular}

果実類 $(r=0.401)$, 海草類 $(r=0.333)$, 調味料 $(r=$ $0.493)$ と強い補完性があるのに，二世の場合では その他の款類 $(r=0.430)$ ，魚介類 $(r=0.243)$, 卵 類 $(r=0.266)$, 調味料 $(r=0.281)$ に補完性があ る. 魚介類についても一世の場合は油脂類, 豆・ 豆製品のほかに卵類 $(r=0.271)$ ，乳・乳製品 $(r=$ $0.286)$, 海草類 $(r=0.469)$, 調味料 $(r=0.389)$ と強い補完性があるのに，二世の場合では米 $(r=$ 0.315)，いも類，豆・豆製品のほかに緑黄色野菜 $(r=0.284)$ に対して補完性がある。肉類について は一世では豆・豆製品のほかに乳・乳製品（r=
$0.424)$, 海草類 $(r=0.387)$, 調味料 $(r=0.476)$ と強い補完性があるのに，二世では菓子類（ $\mathrm{r}=$ 0.286)との間にしかない。これらの食品群の組み 合わせを考えると一世のほうが二世より全般的に 相互関連性が多い。同じ食品群間の相関係数も一 世の方が高い傾向がある。

5. 食物消費構造を決定している因子

1）世代別分類をしない場合

食品群摂取量の相関係数行列 Table 6,7,8 よ り，在日韓国婦人の食物消費構造を決定している 因子を探索するために，主因子法による因子分析 
Table 9 Factor loading value in terms of principle factor

-Korean women in Japan-

\begin{tabular}{lrrrrrc}
\hline Food Groups & Fac 1 & Fac 2 & Fac 3 & Fac 4 & Fac 5 & Communality \\
\hline 1. Rice & 0.164 & 0.100 & -0.455 & 0.106 & -0.036 & 0.256 \\
2. Bread & 0.005 & -0.223 & 0.334 & -0.041 & -0.160 & 0.189 \\
3. Noodles & -0.127 & 0.463 & 0.500 & -0.027 & 0.020 & 0.481 \\
4. Other Cereals & 0.284 & 0.225 & -0.151 & 0.016 & 0.083 & 0.161 \\
5. Potatoes & 0.387 & 0.079 & -0.119 & 0.050 & -0.097 & 0.182 \\
6. Sugar & -0.320 & -0.079 & -0.037 & 0.147 & 0.388 & 0.282 \\
7. Confectioneries & 0.018 & 0.032 & -0.140 & -0.198 & 0.334 & 0.172 \\
8. Oil and Fats & 0.528 & -0.645 & 0.298 & 0.067 & 0.043 & 0.790 \\
9. Pulses & 0.589 & 0.236 & -0.166 & 0.082 & -0.166 & 0.464 \\
10. Fish & 0.357 & 0.033 & -0.142 & 0.180 & -0.138 & 0.020 \\
11. Meats & 0.239 & 0.119 & 0.018 & -0.073 & 0.345 & 0.196 \\
12. Eggs & 0.425 & -0.159 & 0.253 & 0.449 & -0.015 & 0.472 \\
13. Milk & 0.573 & 0.192 & -0.084 & -0.210 & 0.027 & 0.417 \\
14. Green Vegetables & 0.419 & -0.406 & -0.121 & -0.251 & 0.067 & 0.422 \\
15. Other Vegetables & 0.387 & -0.083 & 0.079 & -0.353 & 0.089 & 0.295 \\
16. Fruits & 0.487 & 0.074 & 0.046 & -0.295 & 0.024 & 0.322 \\
17. Seaweeds & 0.370 & -0.021 & -0.063 & 0.258 & 0.094 & 0.216 \\
18. Beverages & -0.310 & -0.166 & -0.068 & 0.112 & 0.334 & 0.252 \\
19. Seasonings & 0.493 & 0.315 & 0.252 & 0.300 & 0.269 & 0.563 \\
20. Kimchies & -0.176 & -0.136 & -0.316 & 0.161 & -0.121 & 0.190 \\
21. Processed Food & -0.100 & 0.145 & 0.319 & -0.114 & -0.144 & 0.166 \\
\hline Eigenvalue & 2.774 & 1.230 & 1.125 & 0.854 & 0.716 & \\
PCT of VAR (\%) & 41.4 & 18.4 & 16.8 & 12.7 & 10.7 & \\
CUM PCT (\%) & 41.4 & 59.8 & 76.6 & 89.3 & 100.0 & \\
\hline & & & & & & \\
\hline
\end{tabular}

を行なった，在日韓国婦人の食物消費決定因子は Table 9 のとおりである.1回目の主因分子解で 固有值が 1.0 以上の因子数は 3 で,かつ第 6 因子以 下の奇与率は低いので，第 5 因子までを取り扱 ことにして各食品の関連係数と各因子の寄与率を 計算した。その結果第 3 因子までの累積寄与率は $76.6 \%$ である゙，元の 22 因子で計算した場合の第 3 因子までの寄与率は $33.3 \%$ あるる。た，各食 品群の共通性を見ると, 油脂類 (0.790), 調味料 (0.563)，めん類 $(0.481)$ などが在日韓国婦人の 食物消費を特長づける食品群である. 以下, 第 1 , 第 2 因子を中心に因子分析の結果を記述する.

(1) 第 1 因子

第 1 因子で大きい正值の因子負荷量をもつ食品 群は豆・豆製品, 油脂類, 乳・乳製品である.さ らに他の食品群もめん類, 砂糖類, 嗜好领料, キ ムチ類，加工食品を除くすべてが正值の因子負荷
量を得ているので多食性を意味していると考えら れる。これらのことを勘案して第 1 因子は副食品 （とりわけ豆・豆製品, 油脂類, 乳・乳製品が大き い比重を有する）を多食する因子と読み取れる。 なお，その対立概念としては嗜好飲料，砂糖など を多食する甘味喍好の食品が分析されている。

(2) 第 2 因子

第 2 因子負荷量では油脂類 $(-0.645)$, めん類 （0.463）が最大值であり, 緑黄色野菜 $(-0.406)$ もかなり大きい值である，反対概念としてはめん 類, 調味料が表示している. したがって, 油脂・ 緑黄色野菜の因子と読み取れる。

（3）第 3 因子

第 3 因子負荷量では米 $(-0.455)$, めん類 (0.500) パン (0.344) が最大值である.ささらに他 の食品群の因子負荷量も考慮に入れるとパンを多 食する食パターンと米飯中心の食パターンとの対 
Table 10 Factor loading value in terms of principle factor

-First generation Korean women in Japan-

\begin{tabular}{lrrrrrc}
\hline Food Groups & Fac 1 & Fac 2 & Fac 3 & Fac 4 & Fac 5 & Communality \\
\hline 1. Rice & 0.098 & -0.424 & -0.098 & 0.205 & -0.546 & 0.539 \\
2. Bread & -0.128 & 0.228 & 0.355 & 0.009 & 0.358 & 0.322 \\
3. Noodles & 0.007 & -0.003 & 0.276 & 0.409 & 0.080 & 0.250 \\
4. Other Cereals & 0.228 & -0.265 & -0.344 & 0.288 & 0.064 & 0.328 \\
5. Potatoes & 0.647 & 0.089 & 0.144 & -0.025 & -0.335 & 0.560 \\
6. Sugar & -0.349 & -0.094 & -0.007 & -0.311 & 0.092 & 0.236 \\
7. Confectioneries & 0.073 & -0.097 & -0.355 & -0.076 & 0.001 & 0.146 \\
8. Oil and Fats & 0.516 & 0.632 & 0.077 & 0.002 & 0.075 & 0.678 \\
9. Pulses & 0.641 & -0.286 & 0.033 & -0.282 & 0.006 & 0.573 \\
10. Fish & 0.420 & -0.059 & 0.360 & -0.260 & 0.150 & 0.363 \\
11. Meats & 0.390 & -0.196 & -0.131 & -0.055 & 0.375 & 0.352 \\
12. Eggs & 0.305 & 0.127 & 0.485 & -0.054 & -0.249 & 0.409 \\
13. Milk & 0.652 & -0.350 & -0.039 & -0.040 & 0.215 & 0.596 \\
14. Green Vegetables & 0.346 & 0.622 & -0.433 & 0.016 & -0.075 & 0.700 \\
15. Other Vegetables & 0.335 & 0.478 & -0.154 & 0.121 & -0.137 & 0.397 \\
16. Fruits & 0.594 & -0.078 & -0.148 & 0.335 & 0.067 & 0.498 \\
17. Seaweeds & 0.531 & -0.142 & -0.163 & -0.067 & 0.145 & 0.355 \\
18. Beverages & -0.354 & -0.064 & -0.192 & 0.076 & 0.138 & 0.191 \\
19. Seasonings & 0.695 & -0.184 & 0.264 & 0.056 & -0.045 & 0.591 \\
20. Kimchies & -0.242 & -0.122 & 0.074 & -0.228 & -0.301 & 0.221 \\
21. Processed Food & -0.184 & -0.096 & 0.307 & 0.538 & 0.116 & 0.440 \\
\hline$\quad$ Eigenvalue & 3.715 & 1.693 & 1.297 & 1.032 & 1.009 & \\
PCT of VAR (\%) & 42.5 & 19.4 & 14.8 & 11.8 & 11.5 & \\
CUM PCT (\%) & 42.5 & 61.9 & 76.7 & 88.5 & 100.0 & \\
\hline & & & & & &
\end{tabular}

立を意味すると読み取れる。

(4) 第 4 , 第 5 因子

第 4 因子は卵類, 調味料であり，第 5 因子は砂 糖，肉類因子である。

第 1 因子及び第 3 因子を軸として，それぞれの 食品の因子負荷量を 2 次元空間にプロットして見 ると Fig. 2 のごとくになる.

\section{2）一世婦人の場合}

次に世代別に分けて因子分析を行なった，在日 韓国婦人一世の場合, 食物消費決定因子は Table 10 のと怙りである。これも第 5 因子までに限定し て, 分析したものである。 また, 各食品群の共通 性を見ると, 緑黄色野菜(0.700), 油脂類 (0.678), 乳・乳製品 (0.596), 調味料 (0.591), 豆・豆製 品 (0.573), いも類 (0.560), 米 (0.539) などが 一世婦人の食物消費構造を決定する因子に大きく 係っていることがわかる.
（1）第 1 因子

調味料（0.695）をはじめとして，乳・乳製品 (0.652)，いも類 (0.647)，豆・豆製品 (0.641) などが大きい正の因子負荷量を得ている。このこ とから，この因子は調味料・副食品を多食する因 子と読み取れる。

(2) 第 2 因子

第 2 因子負荷量では正の大きい因子負荷量を得 ている食品群は緑黄色野菜 (0.622), 油脂類 （0.632），淡色野菜（0.478）である.そして，そ れとは逆に乳・乳製品などは負の因子負荷量を示 している。この状況から，この因子は野菜・油脂 対米飯の因子と読み取れる。なお，これらの関係 を食物消費の 2 次元空間図（食品）各食品群にプ ロットすると Fig. 3 ごとくになる.

3）二世婦人の場合

次に在日韓国婦人二世の場合の食物消費決定因 


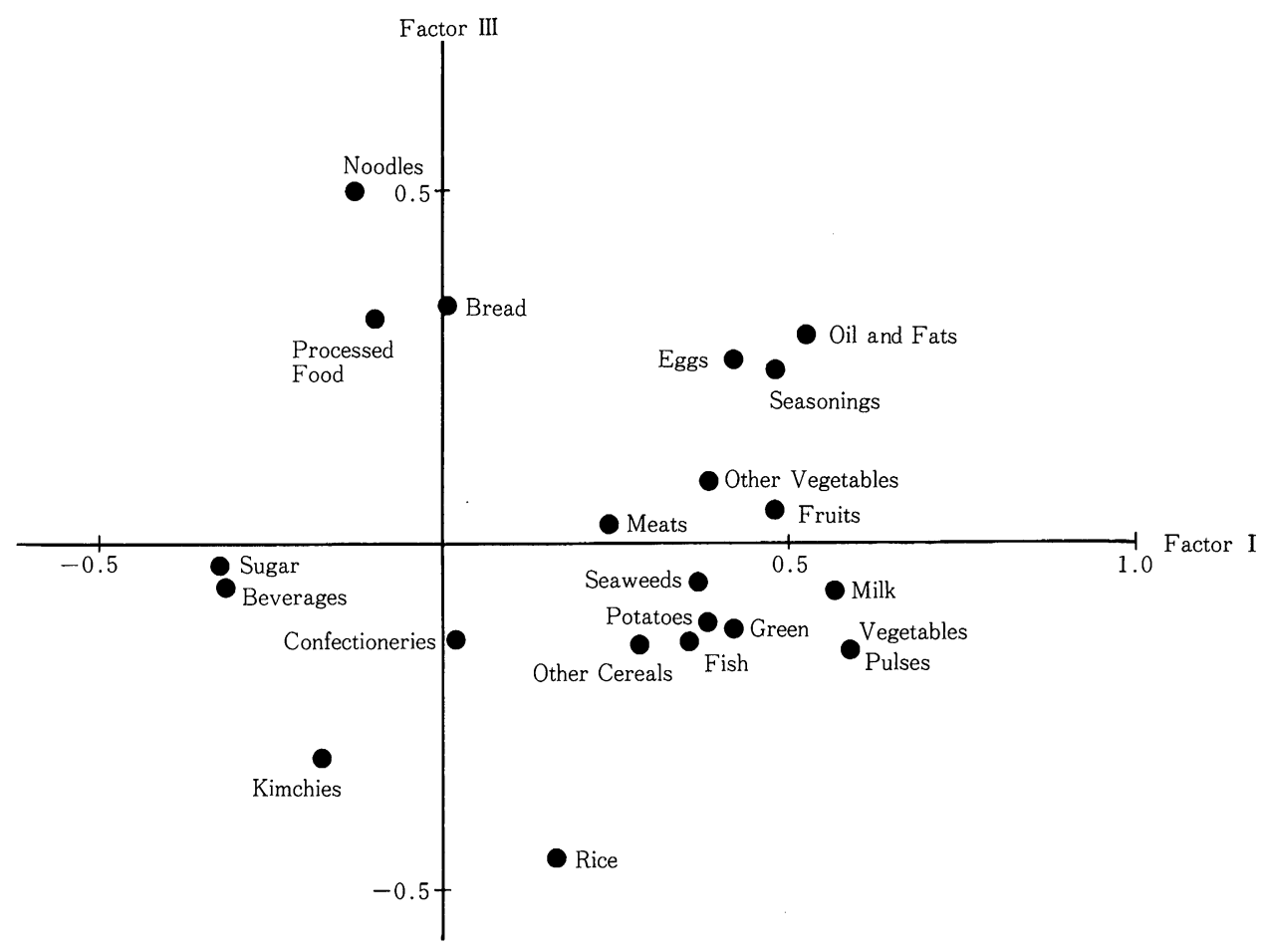

Fig. 2 Spatial location of the major through principle factor analysis for the Korean women in Japan

子は Table 11 に示すとおりである.この因子も あらかじめ第 6 因子まで決めて分析したものであ る。また，各食品群の共通性を見ると，卵類 (0.757), 嗜好领料(0.653), その他の穀類 $(0.620)$, 緑黄色野菜(0.606), 油脂類 $(0.549)$, 米(0.543), パン (0.535)，豆・豆製品（0.530）などが二世婦 人の食物消費状況を特長づける食品であることが わかる。

(1) 第 1 因子

正の高い因子負荷量が与えられてある食品群は 緑黄色野菜 (0.593), 卵類 (0590)，豆・豆製品 (0.559)，乳・乳製品（0.550）などである。ささら にめん類, 砂糖, 菓子類, 喍好领料, 加工食品を 除く多数の食品群が正值の因子負荷量を得ている ので多食性を意味していると考えられる。これら のことを考えて第 1 因子は緑黄色野菜・副食品を 多食する因子と読み取れる。

(2) 第 2 因子
第 2 因子では高い因子負荷量を示している食品 群はめん類 $(-0.508)$, 加工食品 $(-0.350)$, 豆・ 豆製品 $(-0.301)$ などの負値の群と，逆に正值の 米 (0.346), 緑黄色野菜 (0.359), キムチ (0.411) などである。このことからこの因子はめん類対米 飯の対立概念で説明できる因子でありキムチ類は 米飯と結びついていることが示されている。

（3）第 3 因子

第 3 因子の負荷量では米 $(-0.549)$, パン （0.509）が最大値である. 他の食品群の因子負荷 量を考慮に入れて，この因子がパン対米飯をあら わす因子と読み取れる。そして第 1 因子及び第 3 因子を軸とする食物消費の 2 次元空間図（食品） 各食品群をプロットすると Fig. 4 のごとくにな る.

\section{VI 考察}

地理的にも隣接し, 文化的 - 歴史的にも古くて 


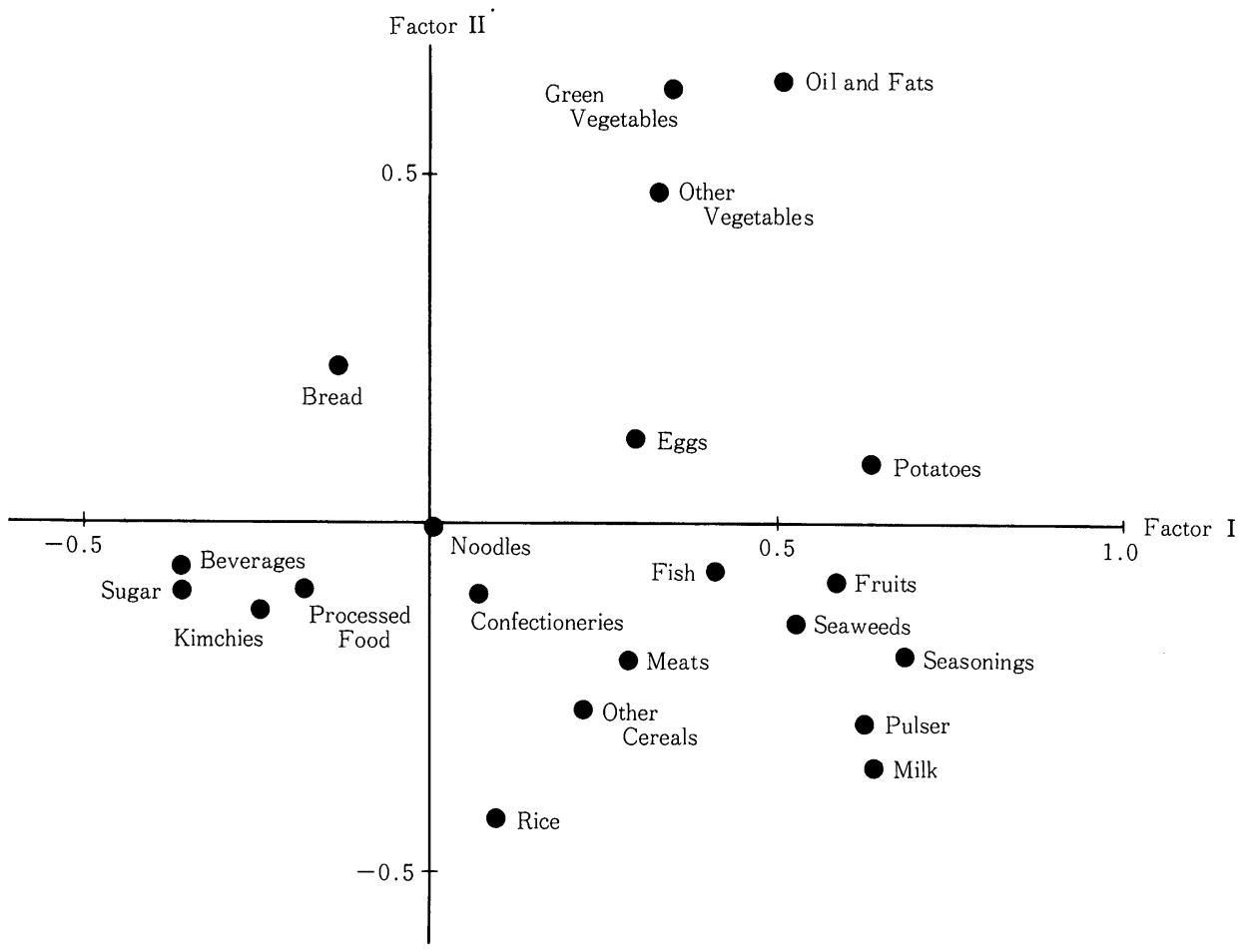

Fig. 3 Spatial location of the major through principle factor analysis for the first generation Korean women in Japan

長い係りを持つ日本と韓国の関係を保健学的視点 から比較・検討することは両国にとって有意義な 情報を提供することになることが十分に期待され

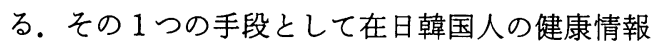
を調査することが考えられる，日本在住の韓国籍 および朝鮮籍（以下これを「在日韓国人」と総称 する)の人口は 660,227 人（1979年 3 月末時点）に 及んでいるが，その大半は太平洋戦争終結（1945 年)以前より居住する者で占められている。近年, 金（1971）金（1977）は在日韓国人の出生力，死 亡, 死因等に関する人口学的研究を通して, 在日 韓国人が非定着的母国回帰型から定着的ないし現 実適応型へと変化していると報告している。本研 究ではその変化を東京都在住の在日韓国人約 100 組の夫婦を対象にして食物摂取状況とその周辺状 況の中に検証しょうとしたものである。もとょり 食物摂取状況は健康現象の一部にすぎないが，社 会心理学的な修飾をらけることが少ないので生活
の実態を把握する手段としてすぐれているばかり ではなく，収集された資料が数量的資料であるの で調査者側の主観的判断が介入しないものである から，地域集団を調査する手段として客観的視座 を確保し易い利点がある。本研究ではこのような 特長を備えた食物摄取状況による実態把握を行な らと共に，食生活周辺状況についても面接聞き取 り法で調查した。これによって食物摄取状況を骨 格とし，その周辺状況を肉付けとして東京在住の 在日韓国人の食生活を疫学調査としてはきめこま かく分析できたと考える。

先ず，下記に主要な事項について個別に考察を 行ない，次いで在日韓国人の食物摂取状況につい て全般的に考察する.

1）一般生活環境

本調查対象は東京都内の, 比較的に多く在日韓 国人の住む地区を選定したが，在日韓国人の大半 は東京, 大阪などの大都市に集中し居住しており, 
Table 11 Factor loading value in terms of Principle factor - Second generation Korean women in Japan-

\begin{tabular}{lrrrrrrc}
\hline Food Groups & Fac 1 & Fac 2 & Fac 3 & Fac 4 & Fac 5 & Fac 6 & Communality \\
\hline 1. Rice & 0.342 & 0.346 & -0.549 & -0.033 & -0.030 & -0.053 & 0.543 \\
2. Bread & 0.142 & -0.047 & 0.509 & 0.347 & -0.025 & -0.364 & 0.535 \\
3. Noodles & -0.270 & -0.508 & 0.132 & -0.257 & -0.140 & 0.078 & 0.440 \\
4. Other Cereals & 0.412 & -0.316 & -0.212 & -0.256 & 0.437 & 0.220 & 0.620 \\
5. Potatoes & 0.180 & -0.149 & -0.192 & 0.378 & 0.420 & -0.114 & 0.423 \\
6. Sugar & -0.296 & 0.311 & 0.153 & -0.001 & 0.318 & 0.354 & 0.434 \\
7. Confectioneries & -0.006 & 0.161 & -0.061 & 0.180 & -0.305 & 0.233 & 0.209 \\
8. Oil and Fats & 0.454 & 0.304 & 0.461 & -0.193 & -0.026 & -0.002 & 0.549 \\
9. Pulses & 0.559 & -0.301 & -0.167 & -0.278 & -0.002 & -0.145 & 0.530 \\
10. Fish & 0.077 & 0.237 & -0.033 & -0.216 & -0.348 & 0.200 & 0.270 \\
11. Meats & 0.077 & 0.237 & -0.033 & -0.216 & -0.348 & 0.200 & 0.270 \\
12. Eggs & 0.590 & 0.213 & 0.429 & -0.409 & 0.061 & -0.095 & 0.757 \\
13. Milk & 0.550 & -0.174 & -0.040 & 0.226 & -0.109 & 0.331 & 0.507 \\
14. Green Vegetables & 0.593 & 0.359 & 0.011 & 0.279 & -0.207 & 0.068 & 0.606 \\
15. Other Vegetables & 0.420 & -0.183 & -0.058 & 0.129 & -0.136 & 0.492 & 0.490 \\
16. Fruits & 0.319 & -0.089 & 0.270 & 0.440 & 0.060 & 0.085 & 0.387 \\
17. Seaweeds & 0.267 & 0.131 & 0.075 & -0.130 & 0.224 & -0.111 & 0.173 \\
18. Beverages & -0.329 & 0.502 & 0.122 & 0.097 & 0.451 & 0.254 & 0.653 \\
19. Seasonings & 0.344 & -0.092 & 0.193 & -0.149 & 0.175 & 0.071 & 0.221 \\
20. Kimchies & 0.014 & 0.411 & -0.946 & -0.010 & -0.191 & -0.218 & 0.291 \\
21. Processed Food & -0.057 & -0.350 & 0.249 & 0.254 & 0.097 & 0.005 & 0.261 \\
\hline Eigenvalue & 2.759 & 1.681 & 1.448 & 1.250 & 1.139 & 1.030 & \\
PCT of VAR (\%) & 29.6 & 18.1 & 15.6 & 13.4 & 12.2 & 11.1 & \\
CUM PCT (\%) & 29.6 & 47.7 & 63.3 & 76.7 & 88.9 & 100.0 & \\
\hline & & & & & & &
\end{tabular}

その傾向はますます増しているので妥当な選定で あるといえよう，在日韓国人の実態調査に詳細な 資料はほとんどないが，それでもいくつかの文献 が得られる（泉端一1951, 洪承稷・韓培浩1979）。 その記述内容と本調査成績とほぼ一致している。 職業について見ると, 零細規模の町工場, 住宅, 小規模な商店が混在密集している地区に住み，対 象者も家内零細工業に従事している人が大半を占 める。その業種はサンダル加工，ミシン加工など の家内労衝による加工業が多くその労衝衛生環境 は有機溶剂による健康障害のおそれが大きい。

生活概況を世代別に比較すると，二世の教育水 準が高く, 生活水準も一世ょり安定している。乙 かし，職業では世代間格差はなく家内零細工業に 従事している人が多い，世代間には事業規模の大 きさの相違や事業主と被雇用者の相違が認められ るにすぎない。

\section{2）食物摄取状況}

在日韓国婦人の食品群別摂取量を日本人（昭和 55 年度国民栄養調査, 全国平均値) と本国在住韓 国人（1980年度国民栄養調査, 全国平均値) の食 品群別摂取量と比較した(Table 12), その結果韓 国に打ける穀類偏重扣よび果実類と動物性食品摄 取量の寡少が認められ, 在日韓国人は日本人と韓 国人の中間に位置する。また，特に婦人の個人レ ベルの食物摄取状況については同じ方法で調査し た神奈川県足柄上群中井町婦人食生活実態調查 （1980）と比較した結果でも両者間にはほぼ同じ傾 向の相違が見出されるが, その差は縮少している. 以上のごとく個別に各食品群の摂取量を比較する と在日韓国人扣よび同婦人は本国在住韓国人より 果実類や動物性食品の摄取量が多い豊かな食事を 営んでいる。しかも，食品群分類は日本・韓国と も合致して扣り，比較するに当たって支障がな 


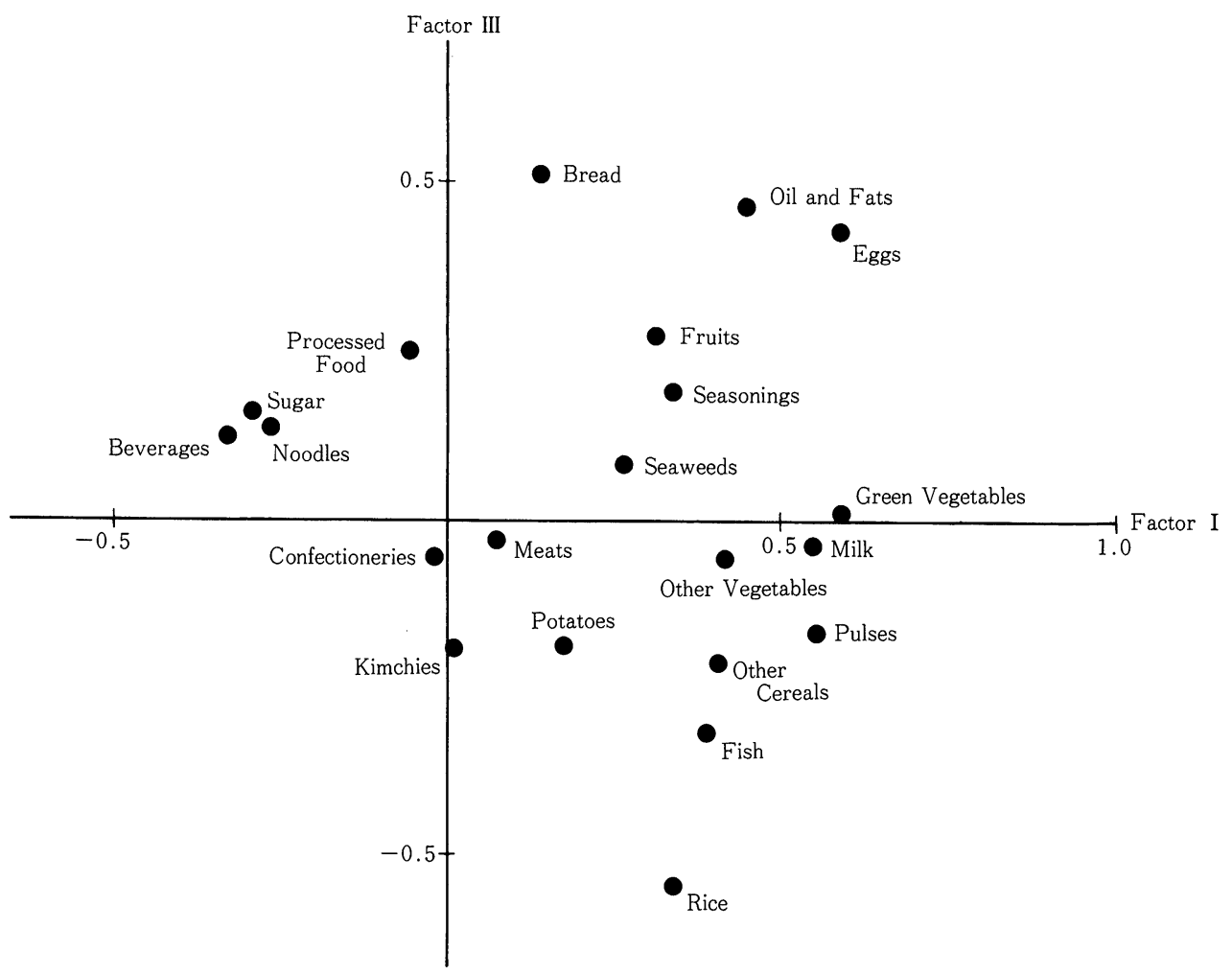

Fig. 4 Spatial location of the major through principle factor analysis for the second generation Korean women in Japan

かったといら事実から両国民の食物摄取状況は基 本的には同じものであると考えることができる. 勿論，キムチの摂取量は有意の差が認められるよ らに, 大分類の食品群ではなく小分類の食品レべ ルで比較したり，また摂取量ではなく，食品の味 付け，調味料のレベルで比較するならばキムチ同 様に両者間に顕著な相違が認められるであろう。 しかし，比較検討することは既に共通する部分が あることを前提とし，非共通点を探し求めるもの であるから，ここでは食品群レベルでの若干の相 違点を明らかにしただけでも意味があるといえよ 5 .

次に，食物摂取状況が生活歴によってどのよう に差があるかを知るために世代を中心に据えて要 因別分析をした，世代間格差が顕著に現われる食 品群はめん類, 調味料, キム千類の摄取状況につ
いてである. 特に, めん類, 調味料は二世で，キ ムチ類は一世で多く摄取されている。金 (1977) のいら定着型ないし現実適応型として把握された ことが食物撕取で起きていることを意味すると同 時に, 香辛料, 調味料などに対する赀好は比較的 強固に継続し，その変化は単なる滞在年数ではな く世代単位で起きることを示すものであるといえ よう。また，世代要因だけではなく他の生活環境 要因も関与して一見，世代要因だけでは説明でき ない食品群が二・三見られる。その中で，特に肉 類は年齢に関して39歳以下では一世婦人がより多 く摂取しているのに，40歳以上になると逆に二世 婦人の方が多く摂取している。これらの不整合性 の原因を説明することはできないが最近本国（韓 国）から結婚のために日本に移住してきた若い主 婦の存在が関与していることが考吕れる。 
Table 12 Comparision of food intake ( $\mathrm{g} / \mathrm{capita}$, a day) among Japanese women, Japanese National Nutrition Survey Data Korean women in Tokyo, and Korean National Nutrition Survey Data

\begin{tabular}{lcccc}
\hline Food Groups & $\begin{array}{c}\text { Korean } \\
\text { Women } \\
\text { in Tokyo } \\
(1981)\end{array}$ & $\begin{array}{c}\text { Japanese } \\
\text { Women } \\
\text { in Nakai-Cho } \\
(1980)\end{array}$ & $\begin{array}{c}\text { * Jpn. Nat. } \\
\text { Nutr. Survey } \\
(1980)\end{array}$ & $\begin{array}{c}\text { **Kutr. Survey } \\
\text { (1980) }\end{array}$ \\
\hline 1. Rice & 195.1 & 153.4 & 225.8 & 459.5 \\
2. Bread & 59.5 & 32.8 & 48.6 \\
3. Noodles & 18.8 & 46.7 & 43.3 \\
4. Other Cereals & 3.9 & - & 1.5 & 35.8 \\
5. Potatoes & 26.3 & 36.6 & 63.4 & \\
6. Sugar & 9.7 & 11.9 & 12.0 & 35.8 \\
7. Confectioneries & 19.8 & 25.8 & 25.0 & - \\
8. Oil and Fats & 13.2 & 21.4 & 16.9 & 4.4 \\
9. Pulses & 67.1 & 76.8 & 65.4 & 46.9 \\
10. Fish & 80.3 & 74.5 & 92.5 & 65.7 \\
11. Meats & 79.9 & 59.7 & 67.9 & 13.6 \\
12. Eggs & 24.2 & 40.9 & 37.7 & 8.3 \\
13. Milk & 79.7 & 113.2 & 115.2 & 9.9 \\
14. Green Vegetables & 62.9 & 49.2 & 51.0 \\
15. Other Vegetables & 221.1 & 312.4 & 192.3 & 172.0 \\
16. Fruits & 93.4 & 133.6 & 155.2 & 41.3 \\
17. Seaweeds & 3.4 & 3.3 & 5.1 & 1.5 \\
18. Beverages & 2.8 & 62.1 & 31.9 & 1.0 \\
19. Alcohols & 11.6 & 13.8 & 49.8 & 9.2 \\
20. Seasonings & 36.6 & 30.4 & 28.0 & - \\
21. Kimchies & 35.5 & 19.3 & 7.0 & \\
22. Processed Food & 33.3 & - & & \\
\hline
\end{tabular}

*: National Nutrition Survey in Japan (1980), adjusted male adult data not female.

** : National Nutrition Survey in Korea (1980), adjusted male adult data not female.

\section{3）栄養素の摄取量}

日本標準食品成分表とそれに記載されていない キムチ類等については韓国食品成分表を用いて計 算した。在日韓国婦人, 日本人（東京近郊農村婦 人：豊川祐之ほか, 1980), 本国の韓国人と比較す ると Table 13 のと打りである。在日韓国婦人は 日本の農村婦人より, 脂肪, カルシウムが少ない, これは両国の国民栄養調査の世帯単位調査成績に 照らしてやはり似た成績であることから，両国民 の食物消費パターンに由来する差であるといって よいだろう，次に，在日韓国婦人と本国の韓国婦 人の比較はできないが, 蛋白, 脂肪の摄取量は在 日韓国人婦人の方が多く摂っている。そのほか, ビタミン類，ミネラル類をみても，在日韓国人婦 人の方が本国の韓国人よりバランスのよい食事を
しているといえる.

\section{4）食物消費構造}

食物消費構造の研究は豊川ら（1976）によって なされている。しかし韓国ではこのような分析は まだされていないので在日韓国人の食物摄取状況 について試みられたこの結果は注目をひくであろ 5。日本人の世帯単位の摄取状況については国民 栄養調査資料の分析結果を用い，また，女性の個 人単位の摂取状況については神奈川足柄上郡中井 町婦人の食生活実態調查結果（1980）を用いて比 較検討することによって在日韓国人の食物消費構 造の特長を論ずることば可能である. 在日韓国婦 人の食物消費構造では相関 $(\mathrm{p}<0.05)$ がある組み 合わせが中井町婦人より多い。このことは韓国料 理が多種類の食材料を混ぜ合わせる献立であるこ 
Table 13 Daily per caput intake of nutrients for the Korean women in Japan and Japanese, Korean

\begin{tabular}{|c|c|c|c|c|}
\hline Nutrient & $\begin{array}{c}\text { Korean } \\
\text { Women } \\
\text { in Tokyo } \\
(1981)\end{array}$ & $\begin{array}{c}\text { Japanese } \\
\text { Women } \\
\text { in Nakai-Cho } \\
(1980)\end{array}$ & $\begin{array}{c}\text { *Jpn. Nat. } \\
\text { Nutr. Survey } \\
(1980)\end{array}$ & $\begin{array}{l}\text { ** Korean Nat. } \\
\text { Nutr. Survey } \\
\quad(1980)\end{array}$ \\
\hline & 〔females` & 〔females] & {$[\underset{\text { male }}{[\text { adjusted to }]}$} & {$\left[\underset{\text { male }}{\left[\begin{array}{c}\text { adjusted to } \\
\text { ald }\end{array}\right.}\right.$} \\
\hline Energy (Kcal) & 1898.9 & 1892.4 & 2084.0 & 2052.0 \\
\hline \multicolumn{5}{|l|}{ Protein } \\
\hline Total, g & 76.3 & 70.7 & 77.9 & 67.2 \\
\hline (Animal, g) & $(38.0)$ & $(-)$ & $(39.2)$ & $(19.3)$ \\
\hline \multicolumn{5}{|l|}{ Fat } \\
\hline Total, $\mathrm{g}$ & 47.2 & 56.3 & 52.4 & 21.8 \\
\hline (Animal, g) & $(24.9)$ & $(-)$ & $(27.2)$ & $(6.3)$ \\
\hline Carbohydrate, $\mathrm{g}$ & 283.9 & 255.4 & 313.0 & 396.1 \\
\hline Calcium, mg & 484.1 & 528.0 & 535.0 & 598.0 \\
\hline Iron, mg & 13.5 & 12.6 & 13.1 & 13.5 \\
\hline Vitamin A, IU & 1697.8 & 1417.2 & 576.0 & 1688.0 \\
\hline Thaiamin, mg & 1.09 & 0.98 & 1.16 & 1.13 \\
\hline Riboflabin, mg & 1.09 & 0.96 & 1.01 & 1.08 \\
\hline Ascorbic acid, mg & 101.5 & 92.1 & 107.0 & 87.9 \\
\hline Cereals/Energy (\%) & 47.7 & - & 48.7 & 77.4 \\
\hline $\begin{array}{l}\text { Animal protein } \\
\text { ratio }(\%)\end{array}$ & 49.8 & - & 50.3 & 28.7 \\
\hline
\end{tabular}

とと関係があると思われる，すなわち，日本料理 が個々の食材料の持ち味を尊重するために競合的 食品を多く生じがちであること（食生態要因）と， 豊川の指摘するように (1976b), 多食性要因がこ の分析法ではではまだ残っていて，それが補完的 に働くために（分析方法要因）に競合性が弱めら れ，その両者が関与して，相関行列 (Table 6) 負 相関が有意な水準に達しなくなっていると考えら れるそのような傾向は一世（Table 7）と二世 (Table 8) の間でも見られ，一世の方が二世より も有意の相関関係を持つ食品群対が多く，それだ け一世の方が二世よりも型の決まった食物摃取を しており，それはとりもな括さず，日本風の食事 と韓国風の食の混合がなく，より純粋に韓国型の 食事を営んでいることにほかならないと考えられ る.

次に食品群相互関係できわだった状況を呈する 食品群としては砂糖, 調味料がある. 砂糖は在日 韓国婦人の場合は喍好飲料だけに有意な正相関が
あるのに中井町婦人ではいも類, 緑黄色野菜, 淡 色野菜, 調味料など多数の食品群と有意な正相関 がある。また，調味料については在日韓国婦人は めん類, いも類, 豆・豆製品, 肉類, 卵類, 乳・ 乳製品，海草類などと有意な正相関があるのに中 井町婦人はめん類，砂糖だけである。これらのこ とから，在日韓国婦人の食生活では砂糖が料理の 味つけとしてではなく，嗜好飲料を通して摂取さ れる傾向があり, 中井町婦人の食生活では味つけ 用として消費されていることを示すと考えられ る。そして食物摄取状況調査の原票をみると調味 料については在日韓国婦人があらゆる料理に用い られて，かつ種類も多く，量も比較的に多量に用 いるが，中井町婦人はそうではないが，その相違 ないし特長が示されているといえよう。また，在 日韓国婦人では砂糖の摄取量について世代間格差 が認められないが，調味料については世代間格差 があり，一世より二世の方が中井町婦人に類似し た使われ方をしている。このような砂糖・調味料 
など味覚に密接に結びつく食材料が他の食品より も相違を示して扣り, かつ, 調味料の方が砂糖よ りも日本型食事に慣化し易いことが示唆されるこ とは，食生活とくに食物摂取における現実適応に も多面性があることを裏付けるものとして興味深 い

5）食物消費パターン

食物群の因子負荷量拉よび食物消費の 2 次元空 間図（食品）によって示された在日韓国婦人の食 物消費パターンの分析を試みた。その結果は中井 町婦人の食物消費パターンの最大因子，つ主第 1 因子と同じょうに在日韓国婦人も副食品を示す 因子であった。しかし米飯中心型対パン中心型の 食事パターンとして示された因子が中井町婦人 （豊川祐之ほか1978，1979，1980）の場合は第 2 因 子であったが，在日韓国人婦人の場合は第 3 因子 として抽出された。それだけ食物消費構造が異 なっているのであるが，第 3 因子であってもその 固有值は大さいので日本婦人と在日韓国婦人の食 物消費パターンは本質的に異質なものではないと 考えてょいだろう。

次に世代別に在日韓国婦人の食物㩒取状況を因 子分析すると，一世（Table 10）では第 2 因子に 野菜・油脂対米飯中心の食事パターンの因子が抽 出され，かつ二世（Table 11）では第 2 因子にめ 几類中心の食事パターンが抽出され, 第 3 因子で はじめて米飯中心の食事パターンらしきものが抽 出される。これらの結果によって, 日本婦人（豊 川祐之ほか；1980）, 在日韓国婦人一世, 二世の三 者間に微妙ではあるが，連続性を示す関連がある といえよう。しかし，これらの比較ないし变化の 検討は因子分析の解析能や因子の読み取りの確か さ等とも絡んで難しい問題であり，それだけにそ の判断には慎重を期さなければならない。将来, もし，米国の韓国人の基本的食物消費パターンが 把握されるならば四者間の関連について知ること ができるので，本論に拈ける推論の確かさを，上 り正確に判断することが可能になるだろう.

\section{VII ま と め}

本研究は東京都内某地区に住む在日韓国人（約 100 世帯) 婦人を対象に食物摂取状況を調査し, 在 日韓国人の生活状況の変化を明らかにすることを 目的としたものである。本研究の特色は，既に巨 視的に把握された在日韓国人の人口学的变化を生 活現象, とくに食物摄取に焦点を紋って, 微視的 であるがきめこまかい観察を通して明らかにした ことにある.さらに一世，二世（First \& Second generation）によって食物摂取状況を比較検討を 行なっている。その結果次のような知見を得た。

1) 本対象の在日韓国婦人の平均年齢は一世で

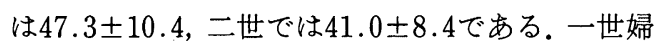
人の平均在日年数は $26.4 \pm 16.8$ であり,ちなみに, 二世の在日年数は年齢之同值である。一世の主な 出身地は済州道 $(62.5 \%)$, 慶尚道 $(22.5 \%)$, 全 羅道 $(7.5 \%)$ である. 教育程度は一世より二世が 高い, 配偶者の職業は家内加工業, 特にサンダル・ ミシン加工等が世代に関係なく最も多い，婦人が 家内工業で配偶者と一緒に働く割合は一世では $60.0 \%$ ，二世では $72.9 \%$ である。供数は一世で は 5 人以上が $22.5 \%$ ，二世は 3 人が $29.2 \%$ て番 多い，平均子供数は一世では $3.2 \pm 1.8$, 二世では

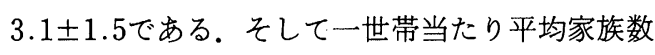

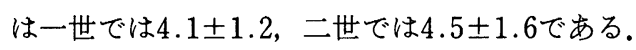
また，対象者の就労年数は二世が平均年龄が低い にもかかわらず一世よりも長い, 現在の生活上の 悩みについては一世が経済問題 (34.2\%) を挙げ ているが，二世では別に悩みはないとするものが 約半数であり子供の問題を挙げるものが $28.3 \%$ も ある。

2) 食品群別摂取量( 1 人 1 日当たりのグラム重 量: 22 食品群別大分類) を生活要因 (年数, 在日 年数）によってどのような差があるかを知るため に世代を中心に据えて分析すると，世代間格差が 顕著に現われる食品はめん類, 調味料, キム千類 でめん類, 調味料は二世で, キムチ類は一世で多 く摂取されている。

3）在日韓国婦人の攝取熱量は1898.9 5552.0 
kcalであり, 栄養素摄取量は日本人の東京近郊農 村婦人の栄養素摂取量に比べてカルシウム, 脂肪 が低值であるが，それ以外ではむしろ高值である。

4）食物消費構造については東京近郊農村婦人 (神奈川県足柄上郡中井町) と比べると, 相関 $(\mathrm{p}<$ 0.05）がある食品群間の組み合わせが在日韓国婦 人の方が多い。そのような傾向は一世と二世の間 にも見られ，一世の方が二世よりも有意の相関関 係を持つ食品群対が多く，それだけ一世の方が二 世よりも韓国型の食事を営んでいることを示して いるためと考学られる，次に食品群相互関係でき わだった食品群としては砂糖, 調味料がある。砂 糖は在日韓国婦人の食生活では料理の味つけとし てではなく，嗜好飲料，つまりコーヒーを飲む時 などに使われているが，中井町婦人の食生活では 味つけ用として消費されていることを示すと考兄 られる。そして調味料については在日韓国婦人が あらゆる料理に種類も多く, 量も比較的に多量に 用いるが，中井町婦人はそらではないことが示さ れている。 また，在日韓国婦人の世代間では砂糖 について世代間に格差が認められないが，調味料 については一世より二世の方が中井町婦人に類似 した使われ方をしていることを考劣ると，調味料 の方が砂糖よりも日本型食事に馴化し易いことが 示唆される。

5）因子分析で分析された食品群の因子負荷量 扣よびそれと図示した食物消費の 2 次元空間因 （食品群）によって，在日韓国婦人の食物消費を決 定づける主たる因子は，第 1 因子に副食品を多食 すること，第 2 因子に油脂・緑黄色野菜を多食す ること,そして第 3 因子は米飯食とパン食パター ンが抽出される．世代別には一世では第 2 因子で 米飯中心の食事パターンなのに, 二世では第 2 因 子でめん類中心の食事パターンで，第 3 因子で米 飯中心の食事パターンが抽出された.

\section{文献}

金 正根 (1971)：在日朝鮮人の人口学的研究, 民族 衛生, 37, 131-157

金 潤信 (1979): 在日韓国人の最近 10 年間における 人口学的推移, 民族衛生, 43, 90-102
豊川裕之（1975）：食生活と健康，大修館
豊川裕之 (1976)：公衆栄養, 光生館
豊川裕之 (1976a)：公衆栄養, 光生館
豊川裕之 (1976b)：計量的食生態学, 生物と化学, 14(6), 409-413

Toyokawa, H.(1978) : Nutritional Status in Japan from the Viewpoint of Numerical Ecology, Soc. Sci. \& Med., Vol. 12, 517-524

東京都足立区（1975）：足立区の人口と世帯，昭和50 年国勢調查

厚生省公衆衛生局栄養課（1981）：国民栄養の現状, 第 1 出版

科学技術庁資源調査会（1978）：三訂日本食品成分表 大韓民国保健社会部（1981）：国民栄養調査報告

森田芳夫（1968）：戦後における在日朝鮮人の人口現 象, 朝鮮学報, 第47輯, 31-76

泉 端一（1951）：東京に扮ける済州道人，民族学研 究, 16

在日大阪同胞健康実態調査実行委員会 (1979)：在日 大阪同胞健康実態調査

洪 承稷, 韓 培浩 (1979): 在日同胞の実態調査, 在日朝鮮人史研究, Vol. 4, 87-147

法務省入国管理局（1979）：在留外国人統計

大韓民国農村振興庁 (1979)：食品分析表

豊川裕之, 他 (1981)：東京近効農村婦人 (30-69 歳) の食物消費パターン，栄養と食䊓，34(6), 531-543

厚生省公衆衛生局栄養課 (1973)：国民栄養の現象(昭 和 46 年度)，第一出版

豊川裕之（1979）：手持ちの食事調査資料を活用する 新しい方法, 公衆衛生, 43(4), 285-291

豊川裕之 (1981)：食物消費パターンの变遷と経済成 長，民族衛生，47, 138-147

片岡邦三, 細谷憲政 (1981): 病気と栄養, 有斐閣 鈴木継美, 他：（1981）：食生活研究 2, 第一出版,

李 誠國，他 (1981)：東京在住の在日韓国人の食物 摂取状況に関する研究，民族衛生， 47, 225

豊川裕之, 他 (1978)：中井町食生活実態調査報告, ライフプランニングセンター

豊川裕之, 他 (1979):

豊川裕之, 他 (197980)：" ”

三宅一郎，他 (1977)：Spss 統計パッヶージ I, II, 東洋経済新報会

柳井晴夫, 高根芳雄 (1978)：多变量解析法, 朝倉書 店

芝 祐順 (1979)：行動科学における相関分析法, 東 京大学出版会

（受稿 1989．3．3） 